\title{
Conservation and Change on Edinburgh's Defences: Archaeological Investigation and Building Recording of the Flodden Wall, Grassmarket 1998-2001
}

\author{
by John A Lawson \\ City of Edinburgh Council Archaeology Service, \\ 10 Broughton Market, Edinburgh EH3 6NU \\ David Reed \\ Bernicia Archaeology, The Old School, \\ 10 North End, Longhoughton, Alnwick NE66 3AG \\ with a contribution by Colin Wallace
}

illustrations by Jonathan Millar and Mike Middleton

Headland Archaeology, 13 Jane Street, Edinburgh EH6 5HE

Scottish Archaeological Internet Report 10, 2003 www.sair.org.uk 
Published by the Society of Antiquaries of Scotland, www.socantscot.org with Historic Scotland, www.historic-scotland.gov.uk

and the Council for British Archaeology, www.britarch.ac.uk

Editor Colin Wallace

Produced by Archetype Information Technology Ltd, www.archetype-it.com

ISBN: 0903903792

ISSN: $1473-3803$ 


\section{Contents}

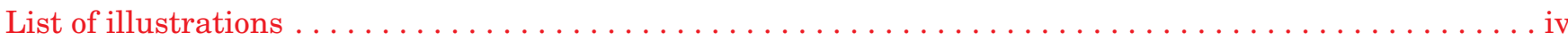

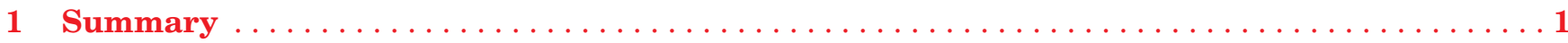

2 Introduction by John A Lawson and David Reed .............................. 3

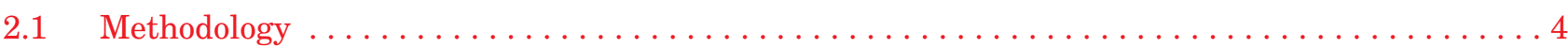

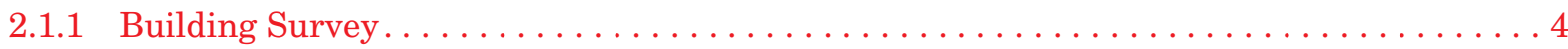

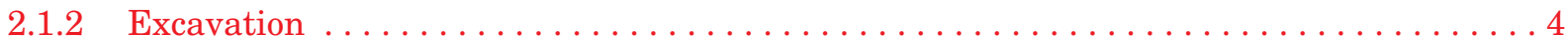

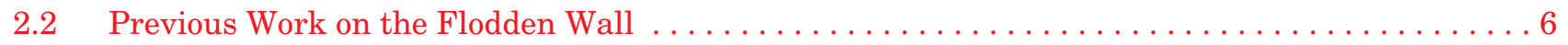

3 Results by John A Lawson and David Reed . . . . . . . . . . . . . . . . . . . . . . . . . 7

3.1 Phase 1: Construction of the Flodden Wall (early 16th century) $\ldots \ldots \ldots \ldots \ldots \ldots \ldots \ldots \ldots$

3.2 Phase 2: Reconstruction and development (16th century $-c 1850) \ldots \ldots \ldots \ldots \ldots \ldots \ldots \ldots \ldots$

3.3 Phase 3: Granny's Green (post 1850) . . . . . . . . . . . . . . . . . . . . . . . . . . . . 10

4 Discussion and Conclusions by John A Lawson and David Reed . . . . . . . . . . . . . . . 11

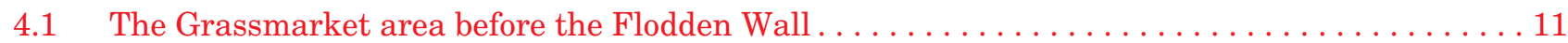

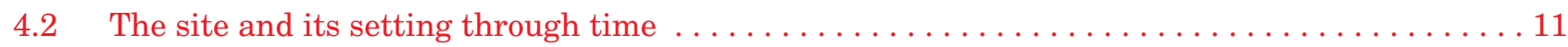

4.3 Late medieval/early post-medieval urban walls in southern Scotland by Colin Wallace . . . . . . . 13

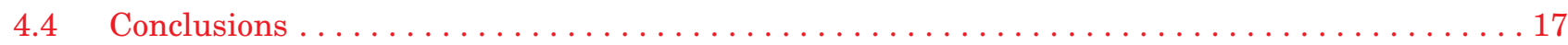

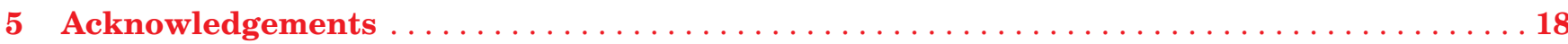

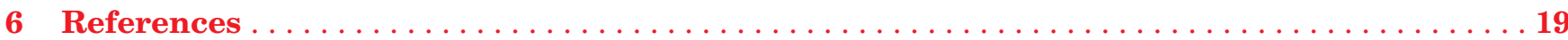

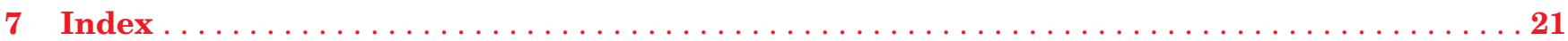




\section{List of illustrations}

Every effort has been made by the City of Edinburgh Council Archaeology Service to obtain permission to use copyright materials in compiling this volume. They apologise here for any omissions or oversights, especially regarding the illustrations, and would welcome these being brought to their attention.

1 Edinburgh's Defences, showing the extent of the Flodden Wall (after RCAHMS) . . . . . . . . . 1

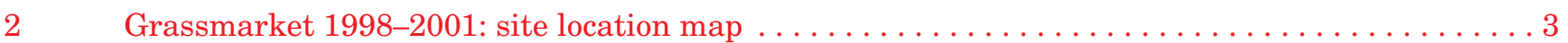

$3 \quad$ Working shot along the top of the Flodden Wall and the Phase $2 \& 3$ walls, facing south at the south-east corner of the Dance Base site $\ldots \ldots \ldots \ldots \ldots \ldots \ldots \ldots$

4 Plan and Elevations (west and east sides) of the Flodden Wall at the Dance Base site ........5

$5 \quad$ West-facing elevation of the Flodden Wall and the Phase $2 \& 3$ walls, to the north of the site . . 6

$6 \quad$ West-facing elevation of the Flodden Wall and the Phase $2 \& 3$ walls, showing Test-Pit C . . . . 7

$7 \quad$ Test Pit C: south-facing section (context 415: Phase 2 rebuild) $\ldots \ldots \ldots \ldots \ldots \ldots \ldots \ldots \ldots$

$8 \quad$ South-facing section of Test Pit $\mathrm{C}$, same view as Illus $7 \ldots \ldots \ldots \ldots \ldots \ldots \ldots \ldots \ldots$

$9 \quad$ The well at the Black Bull, showing the two vaulted feeder drains $\ldots \ldots \ldots \ldots \ldots \ldots \ldots \ldots 9$

10 Plan of the Black Bull well (modern floor joists shown in grey) $\ldots \ldots \ldots \ldots \ldots \ldots \ldots \ldots \ldots$

11 Sketch of the Siege of Edinburgh Castle in 1573, from Holinshed's Chronicles.............. 11

12 Extract from James Gordon of Rothiemay's 1647 plan of Edinburgh . . . . . . . . . . . . . 12

13 Extract from Alexander Kincaid's 1784 plan of Edinburgh . . . . . . . . . . . . . . . . . . . 12

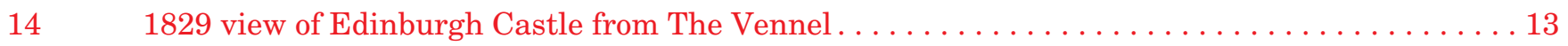




\section{$1 \quad$ Summary}

This report presents the results of a historic building survey and archaeological watching brief undertaken between 1998 and 2001 during restoration work (undertaken as part of the Scottish Dance Base development) on the Flodden Wall running between Edinburgh's Grassmarket and Johnston Terrace. The Flodden Wall is the name given to the 16th-century extension of the capital's town defences, traditionally seen as having been constructed in the months following the defeat at Flodden in 1513 (Illus 1).

Prior to this project the extent and condition of this particular stretch of the Flodden Wall (the northwestern boundary of the Grassmarket and a

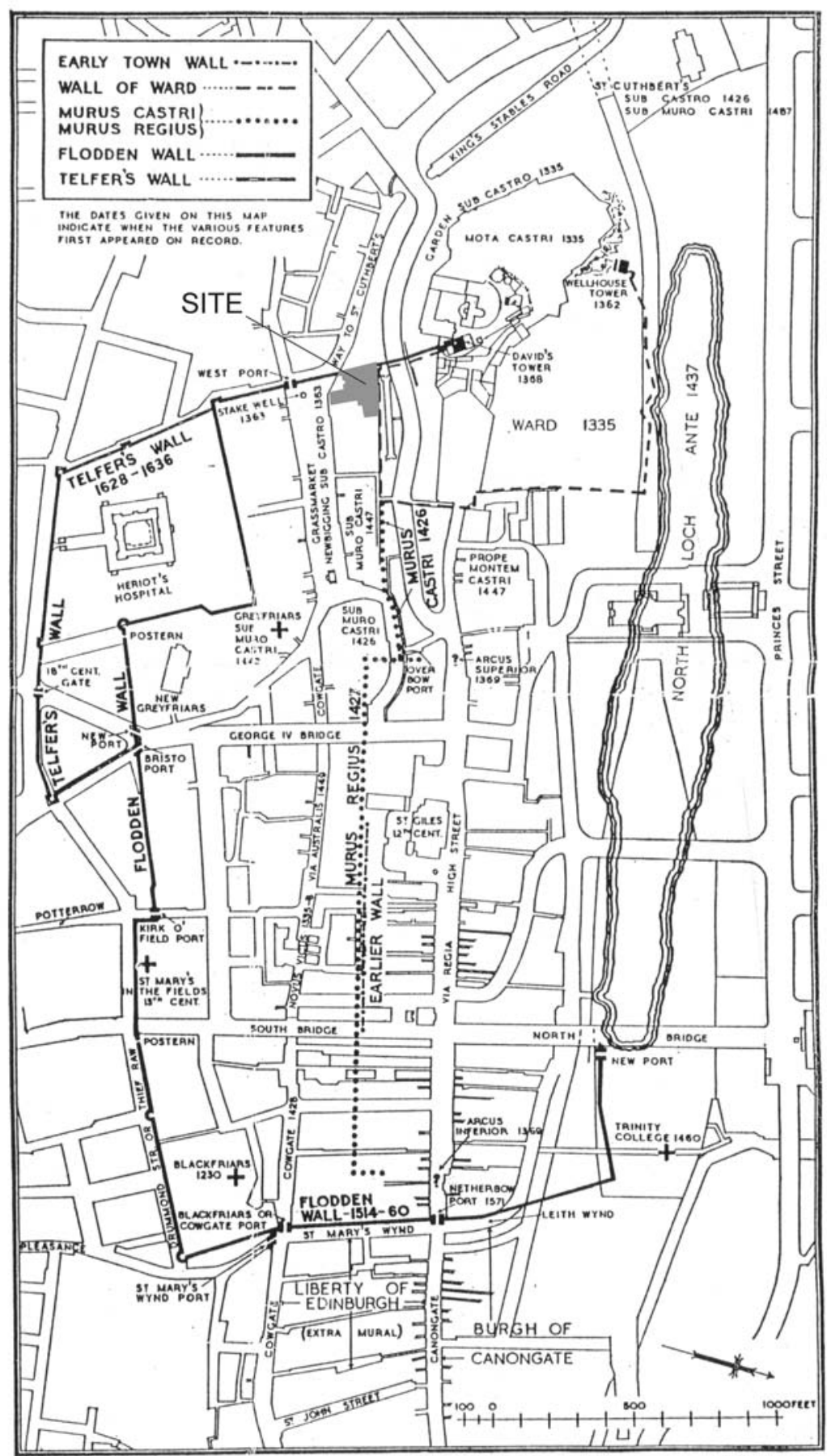

Illus 1 Edinburgh's Defences, showing the extent of the Flodden Wall (after RCAHMS) 
Scheduled Ancient Monument) was not fully understood. This project has shown that here the Flodden Wall and surrounding area had undergone three major phases of construction and redevelopment, from its origins in the early 16th century to the formation of a drying green (Granny's Green) to the west of the Wall in the late 19th century. In particular the results have demonstrated that the surviving southern section of the Wall here was largely rebuilt during the third quarter of the 18th century, when a complex of buildings was constructed along Kings Stables Road abutting the Wall's western face. 


\section{Introduction by John A Lawson and David Reed}

Situated at the south-eastern foot of Castle Hill, the new Scottish Dance Base, opened in the summer of 2001, occupies the north-western corner of Edinburgh's medieval Grassmarket. The development, which started in 1998, saw the extensive refurbishment of the Black Bull public house along with the rest of the properties forming nos. 14-16 Grassmarket. The new dance studios were constructed to

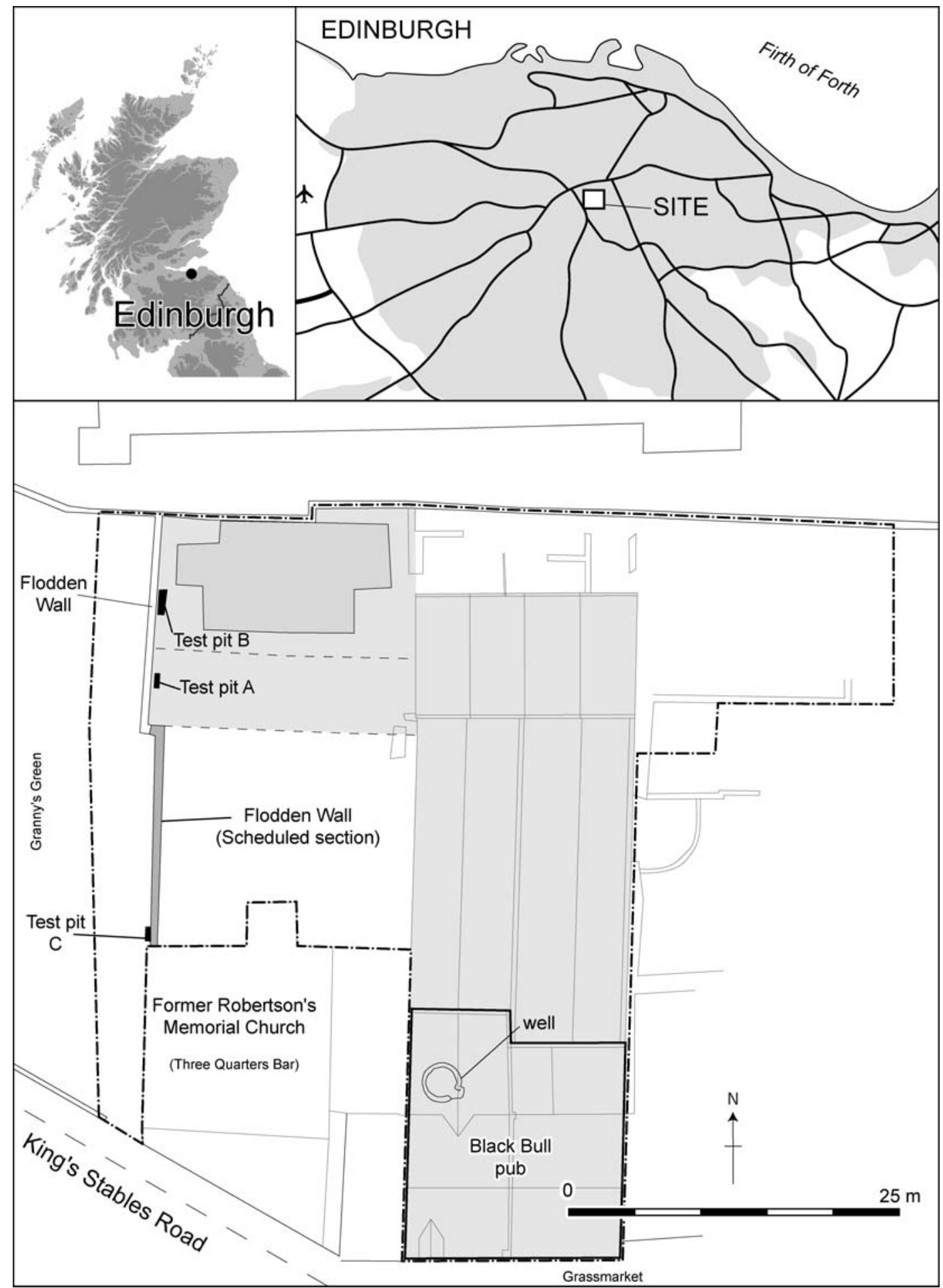

Illus 2 Grassmarket 1998-2001: site location map 


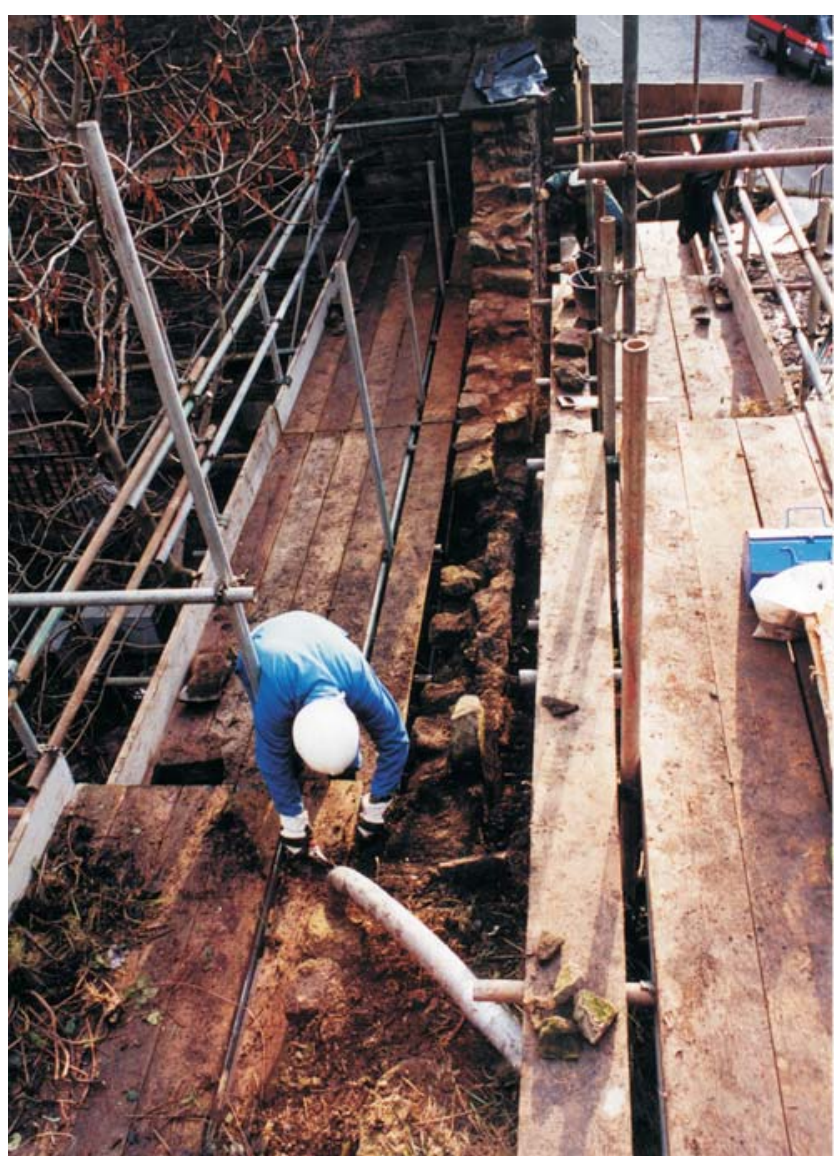

Illus 3 Working shot along the top of the Flodden Wall and the Phase $2 \& 3$ walls, facing south at the south-east corner of the Dance Base site

the rear of these buildings, partially within the gutted interior of a late 18th-century former tenement/warehouse, with extensive new construction across the north of the site. As part of the development there was also a requirement to provide an alternative access route to and from the rear of the complex. This was to be achieved by the construction of a new vennel along the eastern side of Granny's Green linking Johnston Terrace with the Grassmarket to the south (Illus 2).

The construction of the new vennel would involve the demolition and subsequent rebuilding of the upper section of the site's western boundary wall, which faced out onto Granny's Green. The foundations of this wall were known to overly the remains of the Flodden Wall, a scheduled ancient monument (AMH 3012; NGR NT 252 733), which from the early 16th century formed part of the capital's town defences. However prior to the work reported here, the extent and condition of this stretch of the Flodden Wall were not fully understood. The key aims of the project were to try and chart the extent of any original fabric and to trace the urban development history associated with this part of the Flodden Wall.

As stated above the development scheme involved work affecting a scheduled section of Edinburgh's Flodden Wall, running from the north-western corner of the Grassmarket. Accordingly Scheduled Monument Consent was required from Historic Scotland before work could commence. This was subsequently granted with the condition that an archaeological watching brief and historic building survey be undertaken to record any new sections of the Wall exposed, either during consolidation work or as a result of the construction of the new vennel running along the western side of the Wall. The opportunity was also undertaken to widen the historic building survey to include the exposed elevations of the Wall occurring within the development area. The Project Archive will be deposited in due course with the National Monuments Record of Scotland in Edinburgh; the location of the finds will be determined by Historic Scotland's Finds Disposal Panel.

\subsection{Methodology}

\subsubsection{Building Survey}

The programme of historic building recording ran concurrently with an archaeological watching brief during construction works (Illus 3). Because of delays in the construction programme the full programme of building recording on the Wall was not carried out until the winter of 2000/2001 and coincided with the construction of the new vennel. The survey work comprised a detailed photographic survey and scaled plan and elevation drawings of the sections of Wall exposed during development.

A separate photographic survey was undertaken of the late 18th-century tenement situated to the east of the Wall, prior to its part-demolition and conversion to form the main dance studios. The results of this work remain in the project archive.

\subsubsection{Excavation}

Preliminary work in 1998 involved the excavation of three engineering test pits (Illus 2: A, B \& C) against the eastern and western faces of the Flodden Wall. The purpose of these pits was to establish and identify the possible depth of the Wall while also investigating the nature of the deposits accumulated against both sides.

Test Pit A was $0.70 \mathrm{~m}$ square and was excavated to a depth of $1.4 \mathrm{~m}$. Test Pit B situated $4 \mathrm{~m}$ north of Test Pit A, measured $2.1 \mathrm{~m}$ (north south) by $0.70 \mathrm{~m}$ (east west). This test pit was located at the break between the upper and middle terraces and was excavated to a depth of $1.5 \mathrm{~m}$. Test Pit $\mathrm{C}$ located adjacent to the west face of the Wall measured $0.70 \mathrm{~m}$ square and was excavated to a depth of $2 \mathrm{~m}$ below the existing ground surface (Illus 7).

In addition an archaeological watching brief was undertaken during the construction of the new vennel running along the Wall's western face and also during ground-breaking works to the east of the Wall, during 


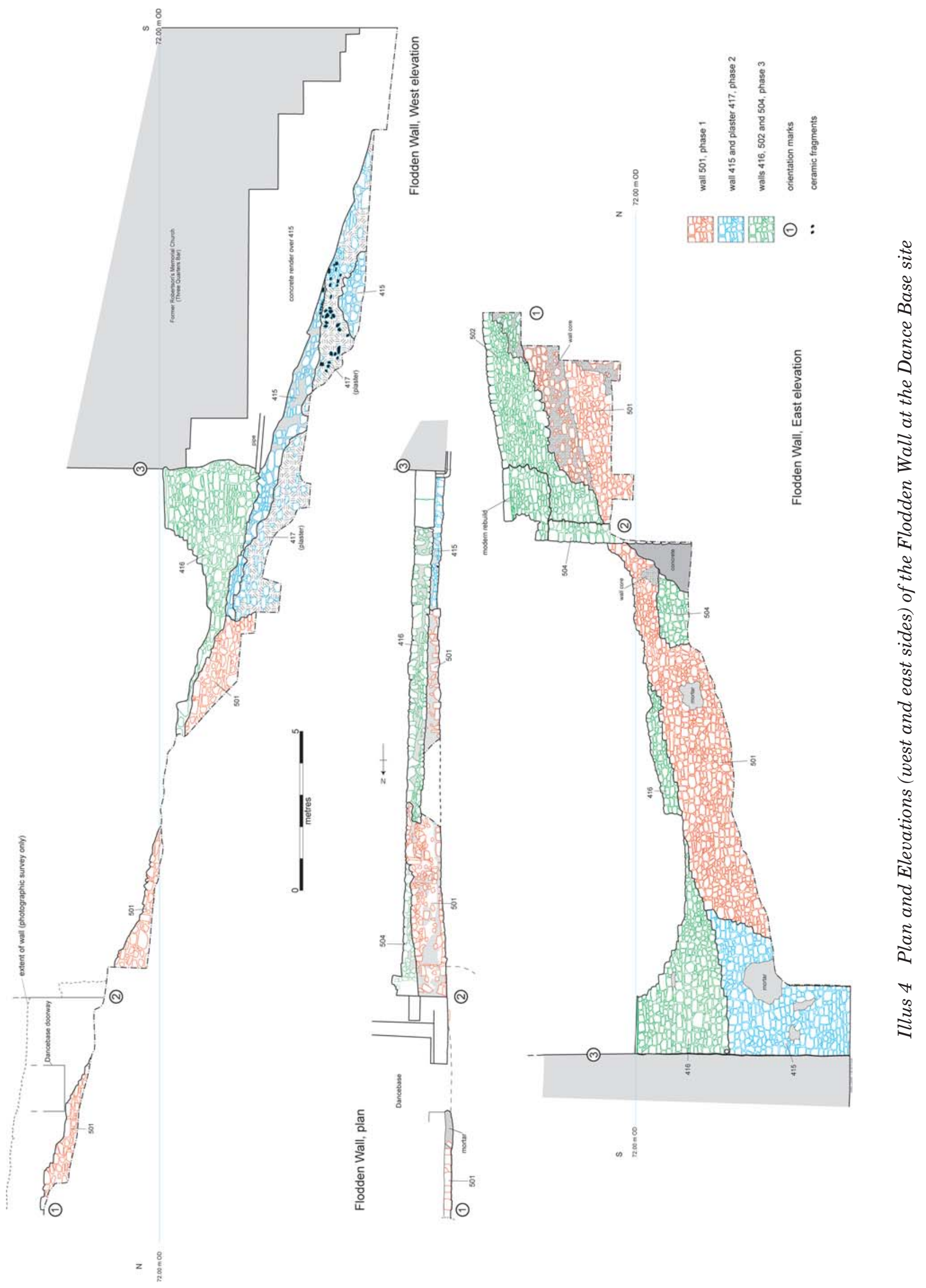




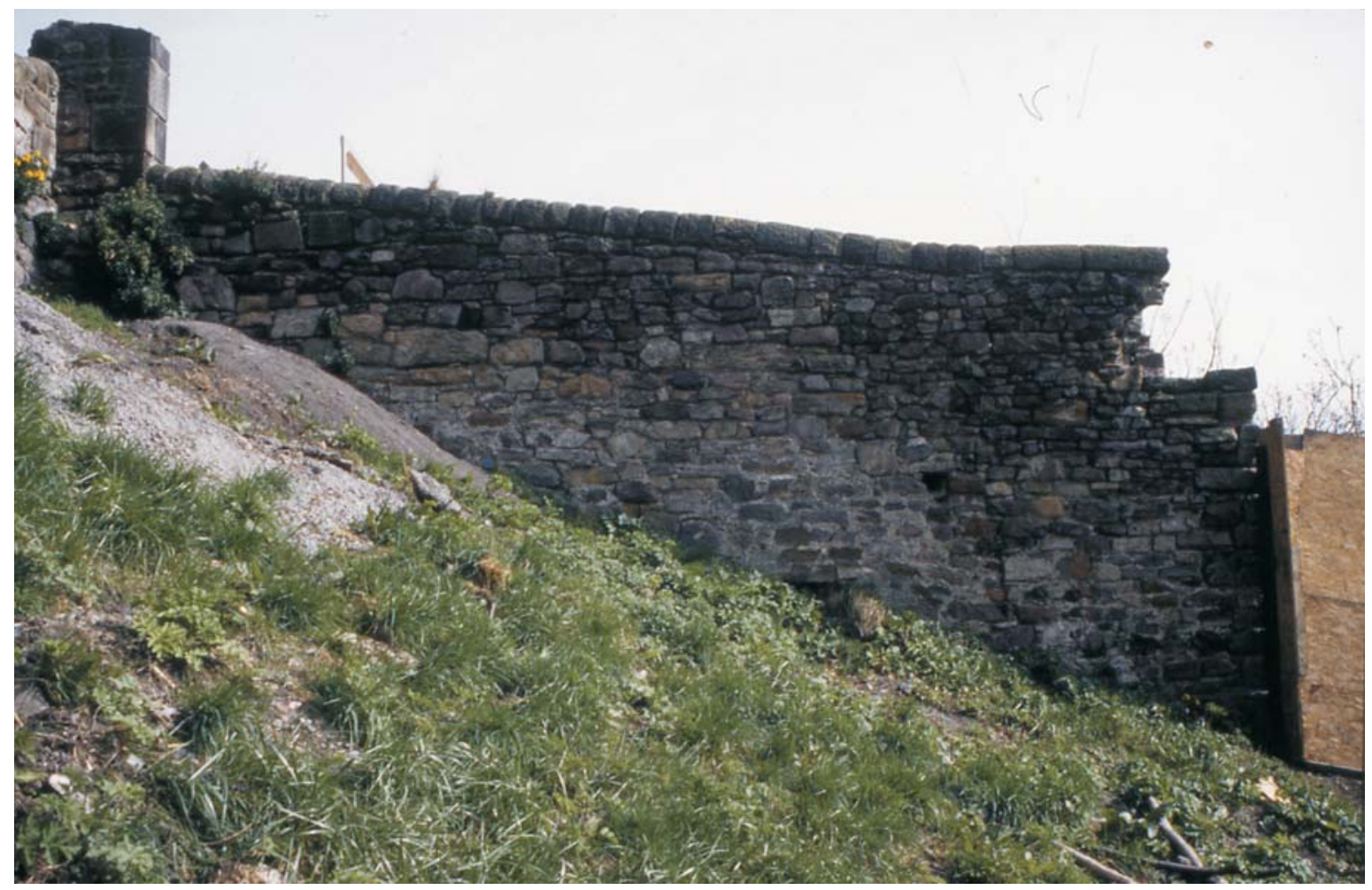

Illus 5 West-facing elevation of the Flodden Wall and the Phase $2 \& 3$ walls, to the north of the site

the construction of the Scottish Dance Base and the refurbishment of the Black Bull public house.

\subsection{Previous Work on the Flodden Wall}

Since the late 1930s fieldwork on the Flodden Wall represented by the Royal Commission Inventory (RCAHMS 1951, 120-21), little additional work has been done on Edinburgh's medieval and later defences. The 15th-century King's Wall was encountered in the High Street excavations of 1973 (Schofield 1978, 181). A surviving stretch of Flodden Wall up to $2.15 \mathrm{~m}$ high was recorded at Chambers Street in 1973 (Tabraham 1973) and the east wall of a building considered to have been put to use as part of the Flodden Wall was excavated at St Mary's Street in 1974 (Holmes 1980, 162). 


\section{Results by John A Lawson and David Reed}

The following results from the archaeological programme of works and building recording have been organised to reflect the three major phases of construction and redevelopment, starting with the construction of the Flodden Wall in the early 16th century.

\subsection{Phase 1: Construction of the Flodden Wall (early 16th century)}

The earliest section of the Wall (context 501: shown in red on Illus 4) - was constructed from random roughly-dressed blocks of sandstone and whinstone, ranging in size from $600 \mathrm{~mm} \times 200 \mathrm{~mm}$ to $150 \mathrm{~mm} \times$ $50 \mathrm{~mm}$. The Wall, which averaged $1.10 \mathrm{~m}$ in width, was bonded together by a buff coloured, lime-based mortar which included frequent inclusions of grit, shell fragments, pebbles and ceramics.

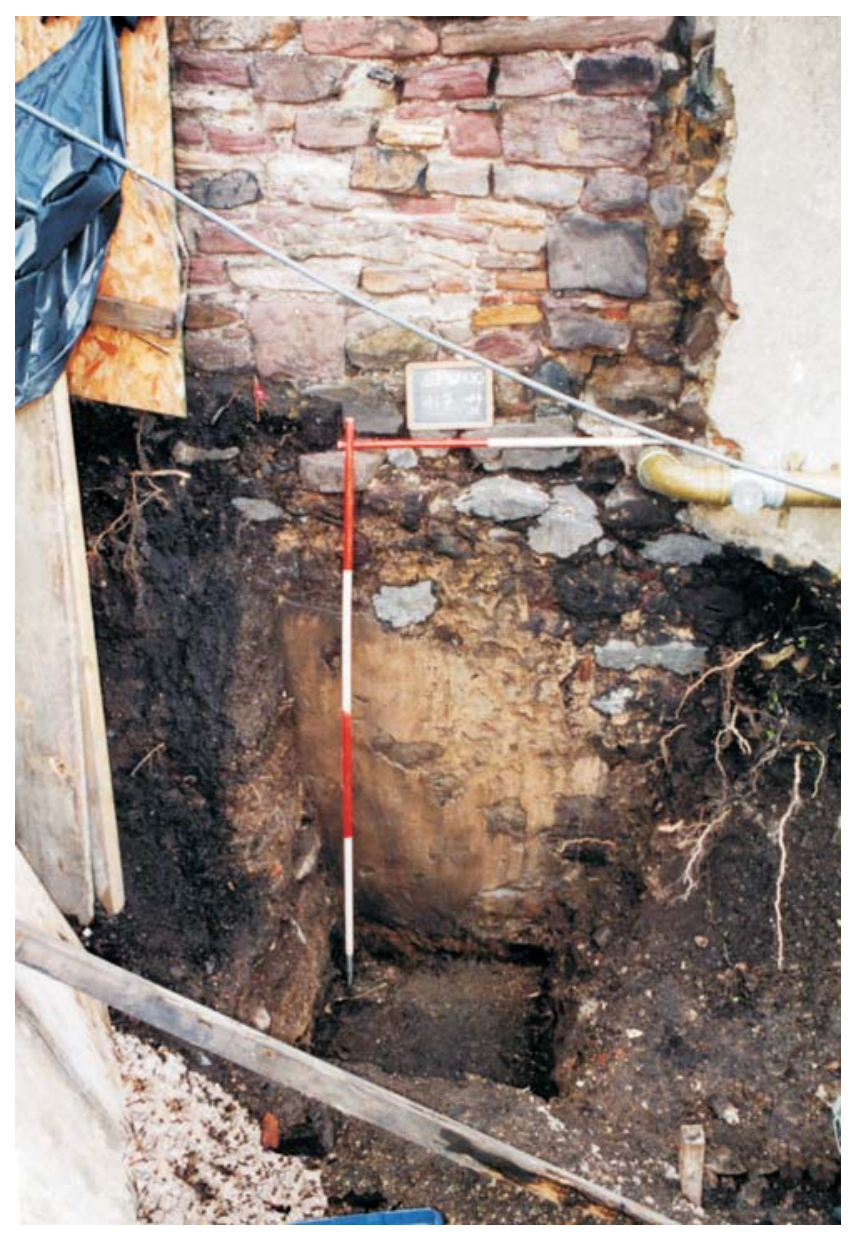

Illus 6 West-facing elevation of the Flodden Wall and the Phase $2 \& 3$ walls, showing Test-Pit C
Although the foundations for Wall 501 were never exposed, the eastern (inner) face of the Flodden Wall was recorded to a height of $2.0 \mathrm{~m}$ above current ground level. It must be noted that the top of this had been truncated, principally in the later 19th century when it was used to form the foundations for the western boundary wall of Granny's Green (wall 416 of Phase 3, Section 3.3). Accordingly the current height of Wall 501 reflects that of the ground level of Granny's Green and not its original height.

At a point approximately $16 \mathrm{~m}$ from the north end of the former Robertson's Memorial Church the Wall was seen to change alignment slightly towards the north-west (Illus 2). The exact reason for this change is unclear though it may reflect the initial construction of the Wall in separate sections. This change in alignment would seem to reflect a change in direction depicted on the 1573 sketch in Holinshed's Chronicles (Illus 11) for this section of the Flodden Wall, though the change shown on this sketch is much more exaggerated.

Within Test Pit $\mathrm{C}$ the foundation trench (context 423) for the 18th-century rebuild of the Flodden Wall (wall 415) was identified as cutting an earlier deposit of dark pink-brown clay (Illus 7, context 422). This layer contained both midden material (animal bone and oyster shell fragments) and quantities of rubble. The rubble comprised large angular sandstone and igneous blocks similar to those used in the construction of the Flodden Wall. Although no dating evidence was recovered, the stratigraphic evidence indicates that this layer formed the outer ground surface contemporary with the Flodden Wall.

\subsection{Phase 2: Reconstruction and development (16th century- c1850)}

Wall 415 (shown in blue on Illus 4) represents the rebuilding of the southern section of the original Flodden Wall (context 501), extending southwards from a point $4.50 \mathrm{~m}$ to the north of the former Robertson's Memorial Church to the Grassmarket. This probably coincided with the construction of a group of buildings either side of the Wall, to the west between 1765 and 1784 and to the east between 1765 and $1810 \times 1817$ (on the map and plan evidence, see Section 4.2).

Wall 415 was constructed using the same roughlydressed sandstone and whinstone blocks as used in the earlier construction of Flodden Wall 501. The rebuilt wall also contained occasional fragments of pantile used as pinnings. This later wall was also bonded together using a different lime-based mortar, 


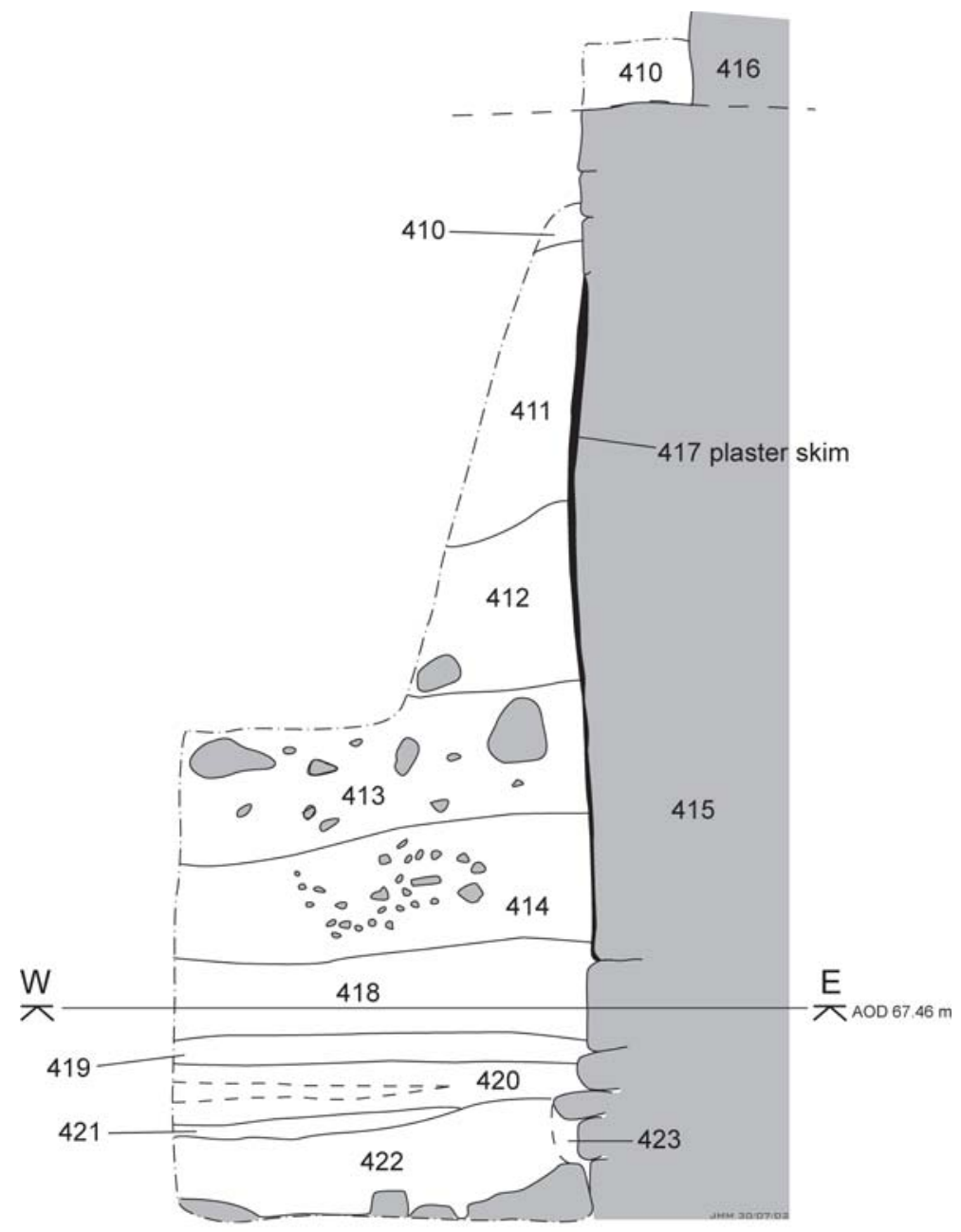

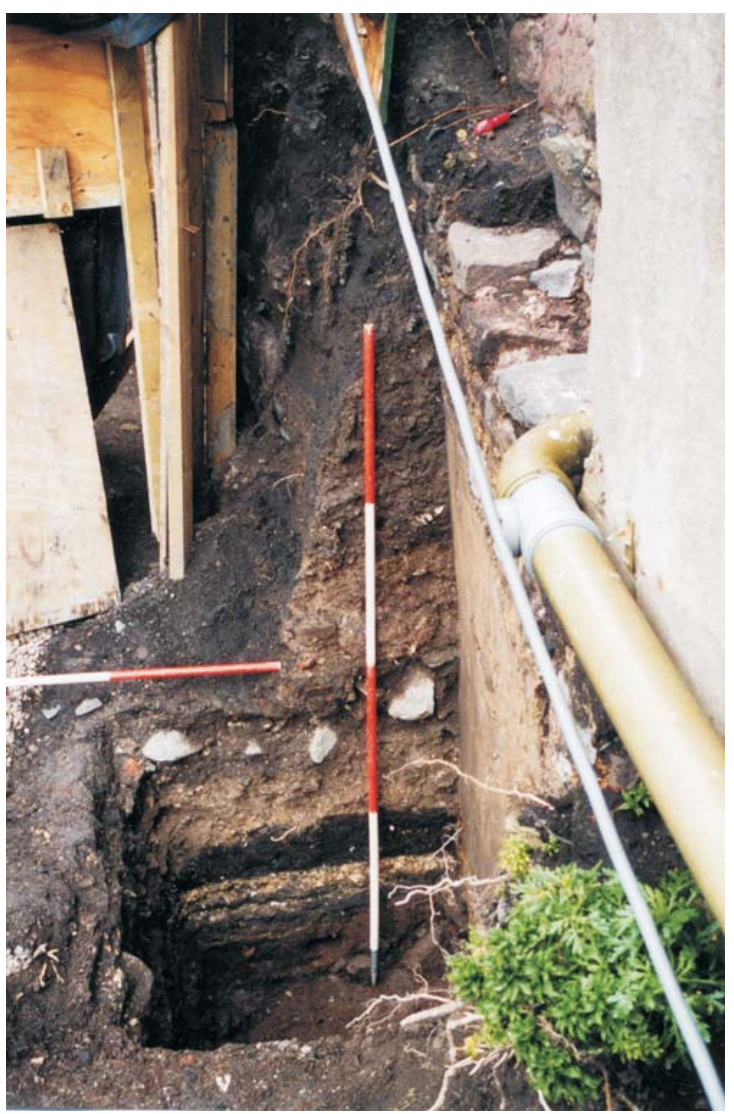

Illus 8 South-facing section of Test Pit C, same view as Illus 7

Illus 7 Test Pit C: south-facing section (context 415: Phase 2 rebuild)

yellow-cream in colour and containing noticeably fewer quantities of sand and grit inclusions. Wall 415 was also narrower than the earlier Flodden Wall (501) averaging $0.80 \mathrm{~m}$ in width in comparison to $1.10 \mathrm{~m}$ for Wall 501 . The narrow foundation trench (context 423) for wall 415 was identified within Test Pit C (Illus 7), cut into the underlying ground surface (422) that had built up against the Flodden Wall (501).

On the western face of the Wall a visible vertical scar marked the change between Walls 501 and 415 on the western elevation (Illus 4). This would appear to respect the position of the northernmost wall for the building shown on Kincaid's 1784 plan of the area (Illus 13). To the south of this scar the Wall's face had been finished with a fine (14mm thick) layer of yellow-brown plaster (context 417) to form an internal surface. To the south of this a second patch of the same plasterwork contained shards of pantile, flattened into the face of the Wall, presumably to form a better bedding surface for the applied plaster.

A uniform levelling layer (Illus 7, context 421) of hard pink-brown, sandy-clay was deposited overlying the irregular surface ground surface 422 to the west of the Flodden Wall, prior to the construction of the later 18th-century building associated with wall 415 and plasterwork 417 (described above). Overlying this layer was a $0.13 \mathrm{~m}$ thick bedding layer (420) for mortar floor 419. This deposit consisted of a firm dark grey-black, sandy silt containing lenses of sandy mortar and also contained artefacts dating to the 18 th century. These included 'hand-made' brick fragments, pottery, clay pipe stems, a fragment of window glass and an undecorated copper-alloy button (finds analysis throughout by John A Lawson). Context 420 overlay both the foundation trench for the rebuilt wall 415 and the clay levelling deposit (421). A $0.07 \mathrm{~m}$ deep floor surface (419) comprised of a hard, friable, cream-coloured lime mortar was subsequently laid over the bedding layer and abutted the internal wall-surface 417. Also contained within the floor surface were lenses of coal, charcoal and coal ash.

To the east of the Wall, the results of the main watching brief and excavation of Test Pits A and B showed that a loose dark brown loam (context 


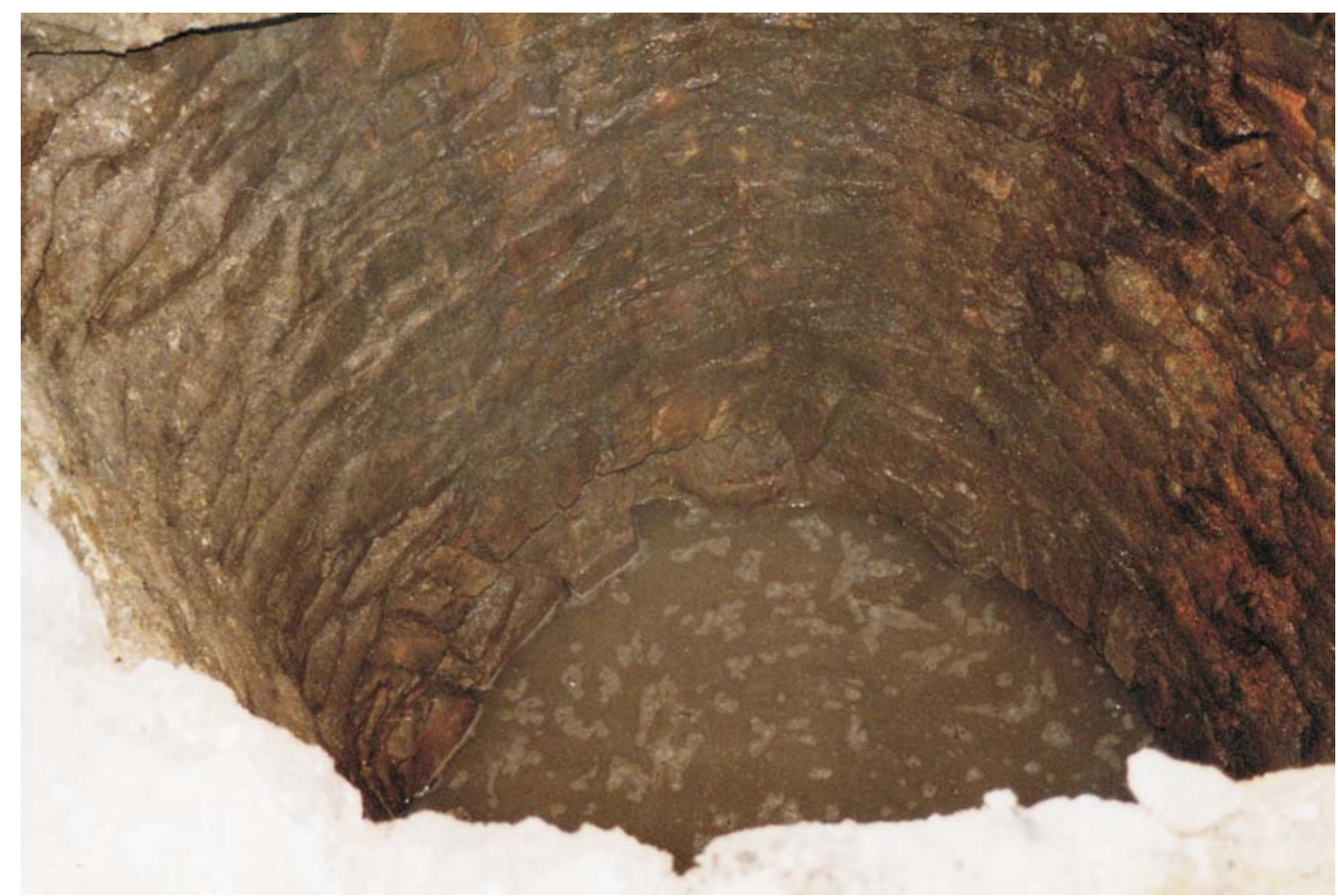

Illus 9 The well at the Black Bull, showing the two vaulted feeder drains

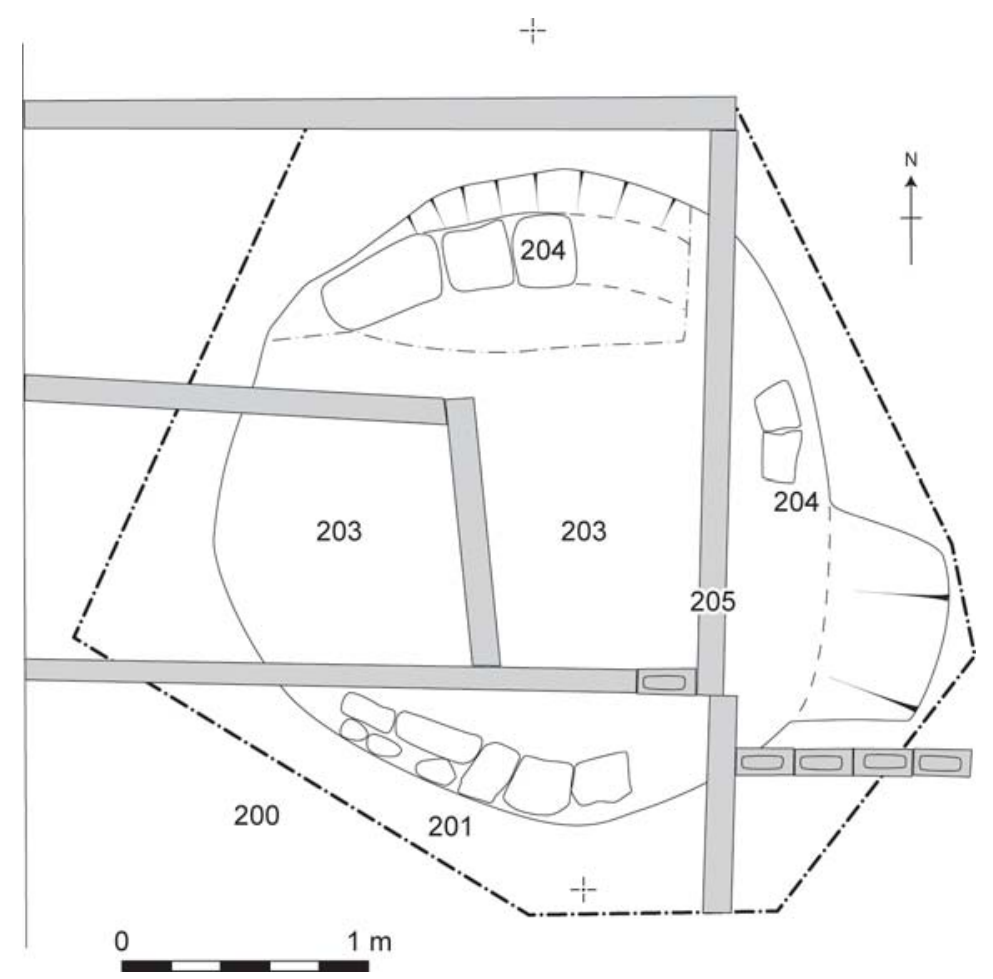

Illus 10 Plan of the Black Bull well (modern floor joists shown in grey)

503/505), with pockets of sandstone rubble, had accumulated to a depth of $0.70 \mathrm{~m}$ to the east of the Flodden Wall. This deposit occurred across the whole area between the eastern side of the Flodden Wall and the late 18th-century tenement, with little differentiation observed. Interpreted as a 'garden soil', it contained small quantities of domestic midden throughout, including animal butchery waste, oyster shells, clay pipe and sherds of 16th-17th century pottery (Westerwald type 
stoneware, Scottish post-medieval reduced and oxidised wares).

A watching brief was undertaken during the relaying of the ground floor of the Black Bull public house. The results showed that the area had been truncated down to the natural reddish-brown clay. However one significant archaeological feature was recorded: well 204, towards the rear (north) of the building (Illus 9). This well (diameter $1.94 \mathrm{~m}$ : Illus 10) was constructed from roughly dressed stone blocks. It had been capped at some point in the last century and the water table was observed at approximately $2.5 \mathrm{~m}$ below the top of the well.

\subsection{Phase 3: Granny's Green (post 1850)}

The mid-19th century saw the undertaking of large scale landscaping on both sides of the Flodden Wall. This involved the demolition of the Phase 2 buildings constructed against the western side of the Flodden Wall and the subsequent creation of Granny's Green. Furthermore, to the east of the Wall the stables belonging to Mr Marshall (according to a plan of Grassmarket properties, 1810: NAS RHP4995 = Adams and Timperley 1988, 42) were demolished to create an upper garden-terrace across the northern half of the area.

This resulted in the construction of a series of new boundary walls (shown in green on Illus 4: 416, 502 \& $504)$ each of which were made from roughly tooled sandstone blocks laid in fairly regular courses with occasional mudstone pinnings. The walls were bonded together with an offish-white mortar containing inclusions of coarse grit and unburnt lime. Only wall 502 retained its original sandstone copingstones (average length $300 \mathrm{~m}$ long), with the remaining sections of wall having suffered from recent collapse. Two modern concrete paving slabs were recorded being used as coping along the surviving upper stretch of wall 416 . Phase 3 wall 502 also contained evidence that recent localised rebuilding and repointing work had been undertaken.

The sequence of demolition/construction and levelling deposits associated with the creation of Granny's Green was recorded within Test Pit C (Illus 7). Overlying the Phase 2 mortar floor 419 was a compact deposit of dark grey-brown, silty-sand containing coal and ash and numerous artefacts (context 418). The artefacts included fragments of 18th-19th century pottery and clay pipe stems, a fragment of window glass, fragments of pantile, animal bone and a copper-alloy circular button. Overlying context 418 and also abutting the Phase 2 plaster rendering (context 417 ) was a $0.20 \mathrm{~m}$ depth of loose, cream coloured, mortar fragments and rubble (context 414). Context 414 contained three 19th-century clay pipe stems (one stamped 'Burns of Leith') and one bowl ('Thomas White of Edinburgh', date-range 1867 x 1880 s).

Overlying context 414 was a $0.38 \mathrm{~m}$ deep deposit of firm dark grey-brown silty-clayey-sand (context 413) contained fragments of stone, pantile, brick and lime mortar. Artefacts within this deposit included a cat's jawbone, two clay pipe stems and a 19th-century clay pipe bowl decorated on the right side with the Prince of Wales' crest. Pottery within context 413 included one sherd of 17th-century Scottish Post-Medieval redware and five sherds of red and white earthenwares dating to the late 18 th to 19 th centuries. This in turn was sealed by $0.26 \mathrm{~m}$ of sandstone rubble within a matrix of loose pink-brown plastic clay (context 412). Numerous fragments of off-white mortar were present within context 412 which also included fragments of pantile, two sherds of 19th-century pottery (white earthenware) and a 19th-century clay pipe stem. Stratigraphically later than context 412 were the foundations for Phase 3 boundary wall 416 (described earlier).

Finally, a dumped deposit of firm dark pink-brown sandy-silty-clay (context 411) overlay layer 412 . This dumped material contained both animal bone and 18th to 19th-century pottery and was overlain by modern topsoil (context 410). 


\title{
4 Discussion and conclusions
}

\author{
by John A Lawson and David Reed
}

\subsection{The Grassmarket area before the Flodden Wall}

The stretch of the Flodden Wall recorded in 19982001 formed the north-western boundary of Edinburgh's historic Grassmarket, which (it has been suggested) originally fell outwith the boundary of the early medieval town (Harris 1996, 27 \& 587). The Grassmarket is likely to have developed during the early part of the 14th century and is first mentioned in the Registrum Magni Sigilii Regum Scotorum in 1363 as 'the street called Newbygging under the castle' (cited in Harris 1996, 306). It is not however until the late 15 th century that its status as an official market is mentioned in an edict of James III (Harris 1996, 306) where it is referred to as the 'Westirmart'. During this period the area housed part of the town's official timber market and also the Friday market for second-hand goods (Harris 1996, 306).

It is not known at what time during the medieval period that the present-day layout of the Grassmarket was formally created. However the linear layout of the properties located along the northern side of the large central market place would appear to reflect a medieval origin. It is likely therefore that these individual burgage plots date from the origins of the market place, in the 14th-15th centuries.

\subsection{The site and its setting through time}

Historically, the Flodden Wall (Illus 1) has been seen as being constructed in the months (and years) following the defeat of the Scottish Forces under James IV, by the English Army at Flodden Field (Northumberland) in September 1513 (e.g. Robertson, Wood \& Mears 1929, 393; RCAHMS 1951, lxiv). The earliest reliable depiction of the Wall is in a sketch of the siege of Edinburgh Castle in 1573, published in 1577 in Holinshed's Chronicles (Illus 11 here; reproduced in The Bannatyne Miscellany Volume II, facing page 74). This sketch depicts the Wall following a roughly zigzag route from the northern corner of Edinburgh Castle's Palace Block towards the West Port, formerly located across the western end of the present-day Grassmarket. The course of the Wall then extended southwards from the West Port along the eastern side of The Vennel before turning eastwards to enclose the southern side of the Grassmarket and Cowgate and then turning northwards along St Mary's Street, ending at the eastern end of the Nor' Loch.

However it is possible to suggest that certain sections of the Wall were not newly constructed post-Flodden, but were a refortification of existing late-medieval town defences. Indeed because the West Port is recorded as early as 1508 x 1509

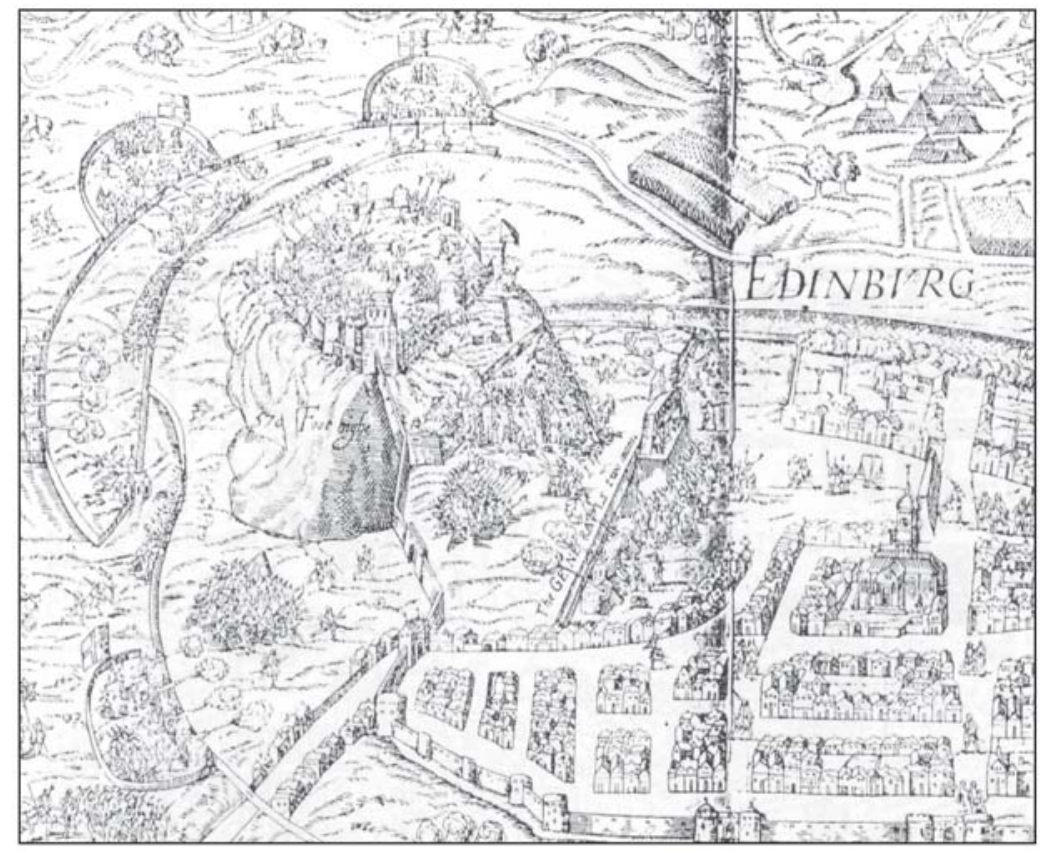

Illus 11 Sketch of the Siege of Edinburgh Castle in 1573, from Holinshed's Chronicles 


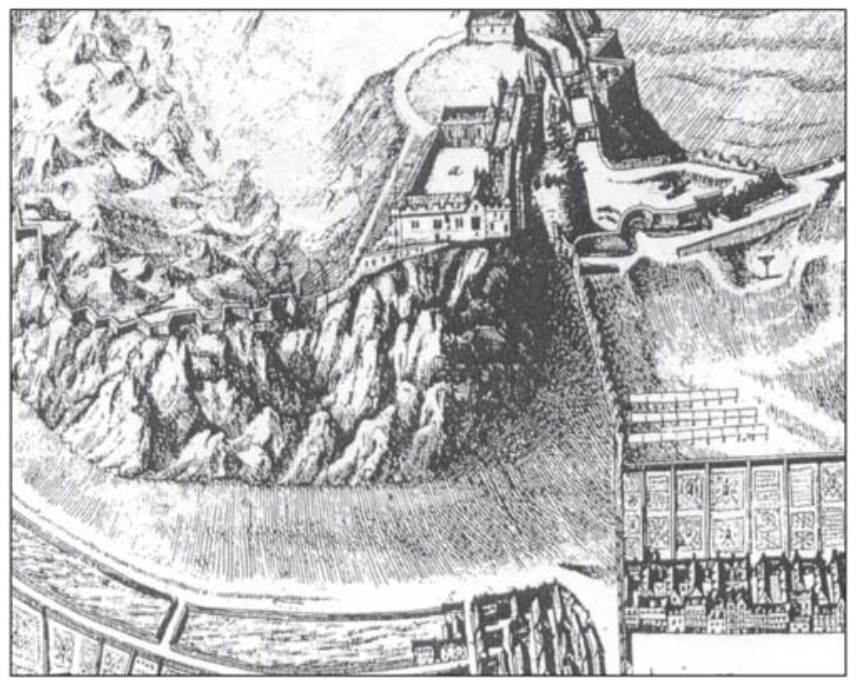

Illus 12 Extract from James Gordon of Rothiemay's 1647 plan of Edinburgh

(RCAHMS 1951, lxiv), it might have been that this particular section of Wall (Phase1, Section 3.1), that links the Grassmarket with Edinburgh Castle (across the line of the post-1828 Johnston Terrace), was already in existence some years prior to its traditional date of construction (Turner Simpson et al 1981, 39; Harris 1996, 273). Recent excavations adjacent to another section of the Flodden Wall, on the southern side in Chambers Street, revealed a medieval ditch that may represent a burgh boundary of earlier date than the Wall (Ewart 1992).

The 16th-century and later depictions of the Flodden Wall also show it to have been crenellated along its length, with towers located at regular intervals southwards from the West Port. These sources also indicate that there was a large defended gateway situated approximately mid-way between the foot of the Grassmarket and Edinburgh Castle. Its position is likely to fall to the north of the site reported here, however, on or close to the route of the present day Johnston Terrace. The sketch in Holinshed's Chronicles (Illus 11) could be read as suggesting that the function of this gateway was to provide direct access to the Castle, possibly acting as a sallyport. The gateway had however disappeared by the time James Gordon of Rothiemay's plan of Edinburgh was made in 1647 (Cowan 1932, nos. 4a \& b: Illus 12 here), to be replaced by a smaller gateway located adjacent to Edinburgh Castle. Rothiemay's

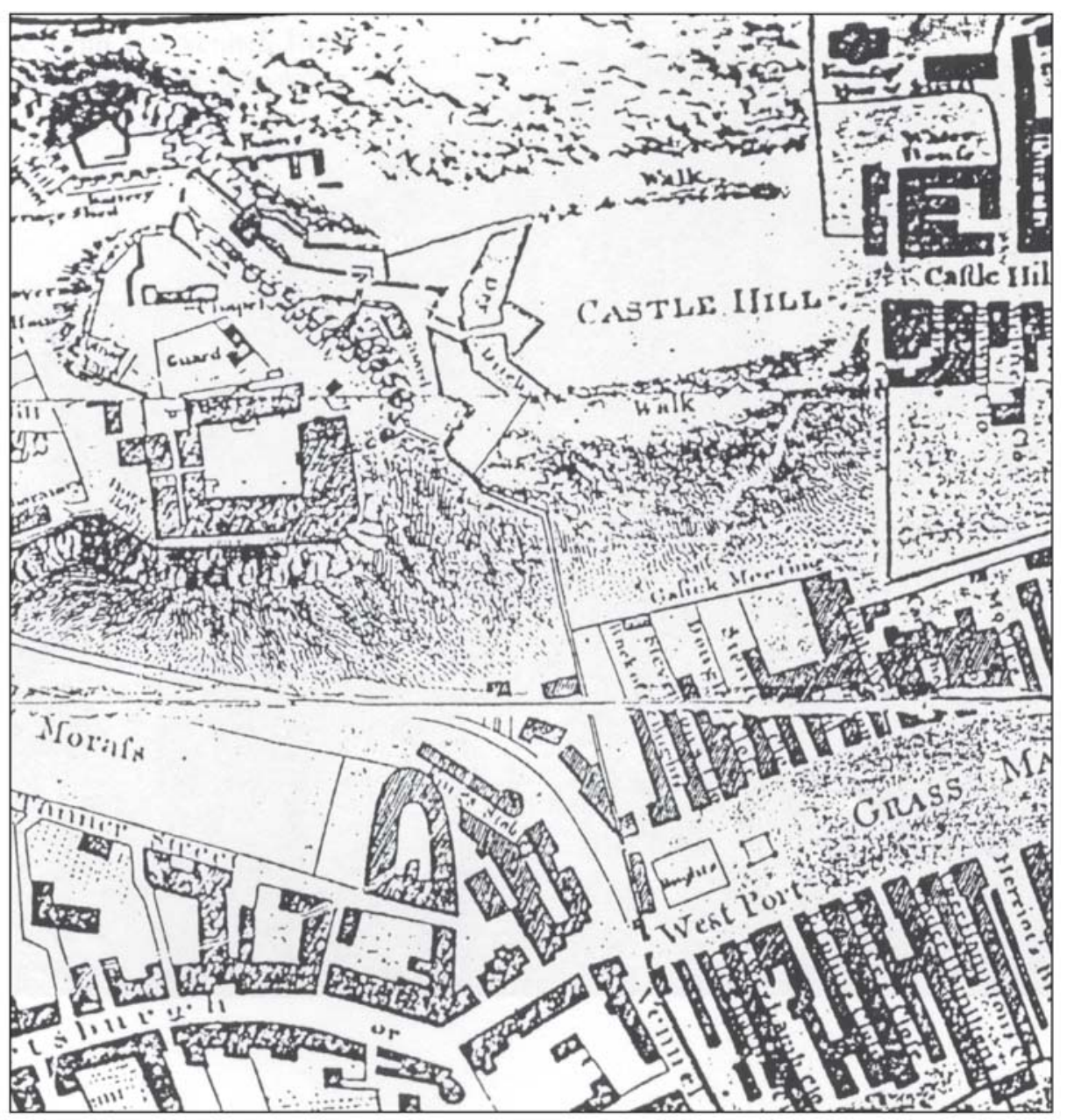

Illus 13 Extract from Alexander Kincaid's 1784 plan of Edinburgh 


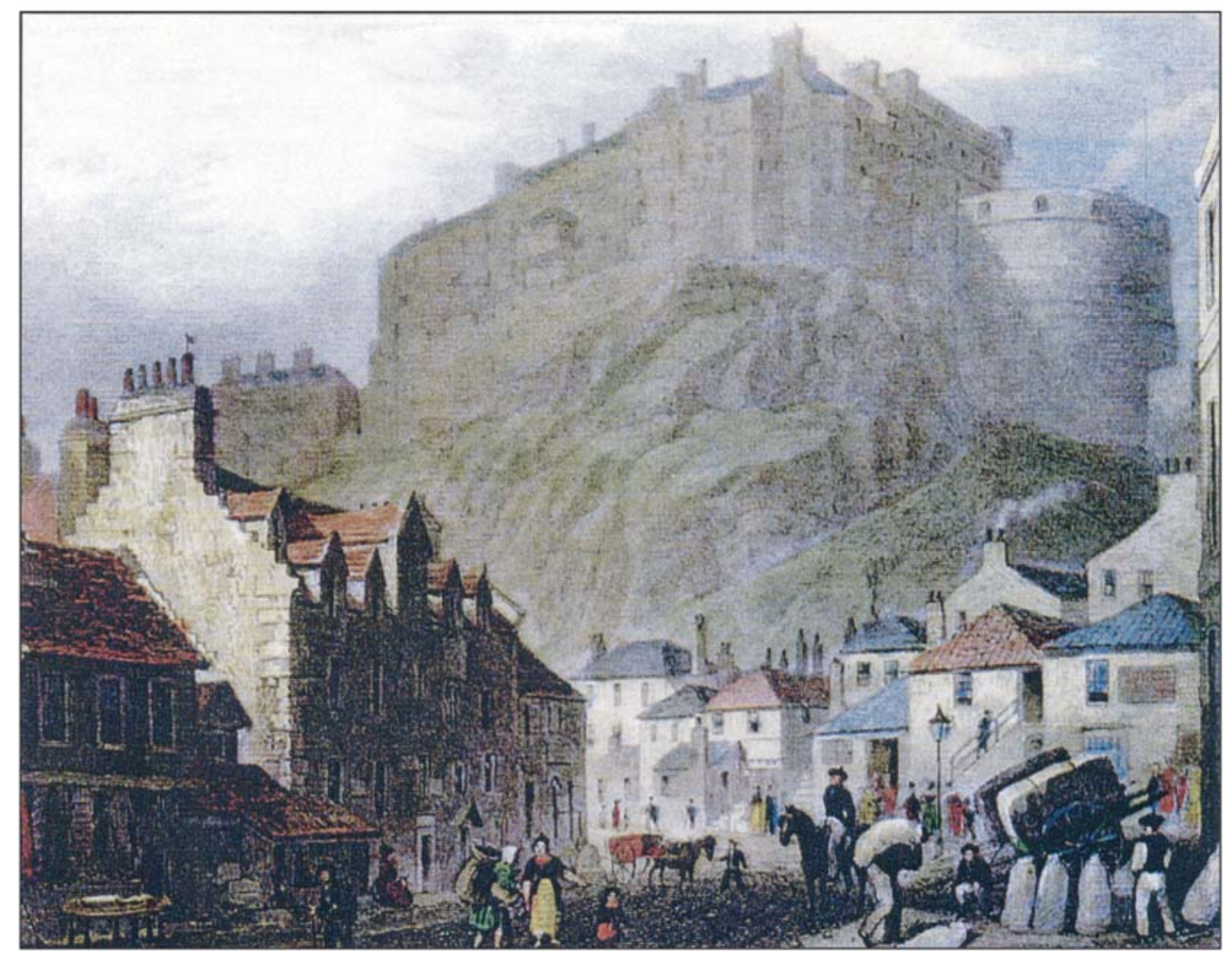

Illus 141829 view of Edinburgh Castle from The Vennel

plan also confirms that the Wall's crenellations were still visible in the mid-17th century.

The area of open ground to the west of the Flodden Wall (Granny's Green) remained free of any development until the third quarter of the 18th century (Phase 2, Section 3.2). It is not until the period between William Edgar's 1742 Plan of Edinburgh (Cowan 1932, no. 5a; updated 1765: Cowan no. 5b) and the 1775 revision of Armstrong's 1773 Plan of the City, Castle and Suburbs of Edinburgh (Cowan 1932, no. $13 \mathrm{~b}$ ) that the first buildings appear in this area. The 1775 plan shows four individual square buildings running along the northern side of the road (King's Stables Road) leading from the Grassmarket to St Cuthbert's Church. By the time of Alexander Kincaid's 1784 Plan of Edinburgh (Cowan 1932, no. 16: Illus 13 here) the original buildings, first shown in 1775 , had been replaced by a complex of structures partly built up against the Flodden Wall. The map evidence further shows that this complex was enlarged by 1817 (for the buildings, see Kirkwood's 1817 Plan of the City of Edinburgh [Cowan 1932, no. 28a]; cf. also the plan of 1810, NAS RHP4995), with additional structures infilling the gaps previously shown between the buildings in 1775 .

A coloured print of Edinburgh Castle from The Vennel, dated 1829 (Illus 14), clearly shows the density of these buildings. This print furthermore indicates that they were a combination of single and multi-storied tenements, roofed with a mix of pantiles (red) and slates (grey). The series of early 19th-century Post Office Directory plans of Edinburgh (Cowan 1932, nos. 25a, 25b, 36a, 36b, $39 \mathrm{a}, 39 \mathrm{~b}$ and $44 \mathrm{a}-44 \mathrm{~h}$ ) show that these buildings survived until $c 1850$. However they were soon to be demolished, as they are absent from the 1st Edition Ordnance Survey 6" map published in 1853.

Granny's Green (Phase 3, Section 3.3) takes its name from the 19th century Wash House that stood to the east of the Flodden Wall, across the northern third of the development site now occupied by a studio of the Dance Base. This building first appeared on the 2nd Edition Ordnance Survey 6" map published in 1877 and survived until its demolition in the late 20 th century.

\subsection{Late medieval / early post-medieval urban walls in southern Scotland by Colin Wallace}

It has been observed that formal urban defences which cost a town a great deal to organise, build and maintain compared to gateways - were rare in Scotland (Stell 1999, 63-64). Perth, with its early 14th-century stone walls (Bowler et al 1996, 927-29) stood almost alone in this respect for many centuries, when elsewhere, earthen defences persisted.

It is notable, however, that the 16 th century - the time of the Flodden Wall - is also the time when more, new town walls are recorded in this country 
than at any other period. Whereas in the 14th century, Scottish armies raided deep into England, from the late 15th century the development of effective siege artillery allowed the attempted reduction of English strongholds. The so-called 'Rough Wooing' of the 1540s (especially the campaigns of the Earl of Hertford, returning as Protector Somerset) somewhat reversed the pattern, with both English raids and large invasion forces targeting Scottish burghs and strongpoints. In the face of new European Great Power alignments, the monarchs James IV, James V, Mary and the regents during the long royal minorities had to cope with the complex, subversive activities of both France and England in 16th-century Scotland. Failures on the battlefields of Flodden (1513) and Pinkie (1547) were only the most visible signs of Scottish military weakness in this age of uncertainty (although it should not be forgotten that the Scottish fight-back was successful: Merriman 2000, 349-67).

The oldest town walls in Northern Britain would appear to be those from just outside the Kingdom of the Scots: the 13th-15th century defences at Carlisle and Newcastle. These two, plus Berwick and Roxburgh of course, were just some of those northern English towns whose stone walls were refurbished or constructed as a result of continuing Scottish incursions in the 14th century. At Carlisle, the series of grants of murage, authorising the citizens to devote the proceeds of tolls to the upkeep of the defences, began in 1232 (Summerson 1993, 123) and the circuit was maintained (through frequent crises) until well into the 16th century. At Newcastle, the earliest surviving murage grant dates to 1265 . The main inland circuit was constructed during the 14th century, with the riverside lengths either side of the bridge over the Tyne added early in the 15th century (Harbottle, in Nolan et al 1989, 29-32; Fraser et al 1994, 145-49). Berwick was walled following its capture in 1296, the start of a series of programmes of defensive works that only stopped in 1569 (MacIvor 1998, 19-29). The development of fortification in Roxburgh probably was similar (up to the town's abandonment) to that of Berwick, with a new stone wall dating from $c 1309$ (RCAHMS 1956, 252-53), during its time as an English Crown possession.

Further north by contrast, the greatest effort seems to have been expended on the single-site fortifications and short-use defences that were within the power of individuals, towns and armies to construct (cf. Caldwell 1984). In the 16th century, when the gun was no longer new technology, examples of this long-lived practice are the blockhouses at Aberdeen and Dunbar harbours (1513 x 1533 and 1515 x 1523 respectively), the advanced defences at Tantallon Castle (1528), the English forts at Broughty, Haddington, Lauder, Eyemouth and Dunglass (1547-51), the French forts at Inchkeith, Leith, Dunbar and Eyemouth (1548-60), the fortifications for the siege of Leith (1560) and the 'keiper dyke' (1579 or earlier) at Annan. The English trace italienne fortifications at Haddington in $1547 \mathrm{had}$ made it one of the first British towns to be so defended (Merriman 2000, 316) but they were abandoned in 1549 and (presumably) dismantled after the Anglo-Scottish Treaty of Norham in 1551, if not earlier.

However, there were some late medieval/early post-medieval urban walls in southern Scotland, which provide a broader context for the Flodden Wall by showing that it was not alone. Edinburgh's first defences (Illus 1) were the subject of royal interest relatively early on: the King's Wall was first recorded in 1427 and further mentioned in royal commands of 1450 and 1472 (RCAHMS 1951, lxii-lxiv), before being overwhelmed on the south side of the burgh at least by later buildings. The undressed sandstone building walls found in 1973 during excavations halfway between the High Street and the Cowgate were possibly part of a joining-together of private walls to form the defensive line recorded in the documentary evidence (cf. Schofield 1978, 181). The expanded circuit of the 16th-century Flodden Wall (Illus 1) has been mentioned earlier in this report (Section 4.2 and Section 2.2); see Section 4.4 for concluding remarks about the evidence from the present site.

With one exception, there is scant evidence for monastic precinct walls in Scotland and what there is is unfortunately inconclusive as to the likely relationship of these construction projects to the town walls discussed below. The earliest section of (excavated) stone precinct wall at Dunfermline Abbey (elevated 1128, the monastery buildings rebuilt after destruction in 1304) was associated with the (broadly-dated) Phase 2 of the 13th/14th century at the Abbot's House site (Coleman 1996, 76-77); elsewhere it was stratigraphically later than the (poorly-dated) 14th- or 15th-century backfilling of an earlier boundary ditch (Lewis 1995, 1028). The monastic precinct wall at Melrose Abbey (founded 1136 , complete rebuilding begun early 15 th century) first appears in 16th-century and later records as the Mantill or Mantle Wall (Curle 1935, 34/43/46), though the gates were recorded much earlier (Curle 1935, 31/36). Too little now survives above ground (e.g. Dennison and Coleman 1998, 73-74) to allow us to compare and contrast its form with the town walls discussed below. At St Andrews, a (new?) precinct wall around the Cathedral and priory, $c 6 \mathrm{~m}$ high and $0.9 \mathrm{~m}$ thick, was constructed and embellished with gun-towers in the first half of the 16th century (RCAHMS 1933, 240-43; cf. John Geddy's coloured bird's-eye plan of $c 1580$ ). The greatest impact of these monastic precinct walls would arguably have been on the adjacent townspeople, rather than the more distant enemy that the burghs of Edinburgh and Stirling at least (see below) claimed to have had in mind.

Archaeologists have often pointed to an act of the Scottish Parliament in 1503 as a general context for the construction of urban defences in southern Scotland, for example in the modern accounts of the 
possible town walls at Dunbar and Inverkeithing (below). According to this, '. . . it is statute and ordanit that all tounis and ports standand on the sey sid sik as Leth, Inverkethin, Kingorn, Disert, Crale and otheris, war [spend] thair comone gudis [the burgh fund, containing the main revenues] on the wallis of thair toune to the sey side with portis of lyme and stane...'(Thompson 1814, 243: 20). Our present knowledge of four of the five places mentioned does not encompass early 16th-century urban defences. The possible exception is Inverkeithing, where W MacKay Mackenzie quoted two 18th-century references to the town walls (Mackenzie 1949, 42); the Scottish Burgh Survey noted the claims that (undated) traces still survive (Turner Simpson and Stevenson 1981a, 6-7 \& 18).

The walls of Stirling are even later than those of Edinburgh, considered to date largely from the 1540s onwards and protecting the town on the south and south-eastern sides. They were rubble built, with gun loops and bastions, to a maximum of $c 6.9 \mathrm{~m}$ high (RCAHMS 1963, 304-06). In 1570, the Burgh Council of Peebles arranged for the construction of a wall around the east and north sides of the town; the circuit was extended in 1572 (Perry, in Dixon et al 2002, 50). This wall was rubble-built, with gun towers, surviving today to a height of $c 2.7 \mathrm{~m}$ (RCAHMS 1967, 280). From 1591 onwards, as a culmination of earlier efforts, a defensive wall was put up on the landward side of the burgh of Dundee, which had been captured by the English in 1547. The new wall linked together the existing (medieval) ports and often used existing walling (Torrie 1990, $56-57 \& 101-03)$. It is claimed to have been $c 4 \mathrm{~m}$ high, rubble-built, with at least one gun tower (Stevenson \& Torrie 1988, 8 \& 15).

In addition, it is sometimes claimed there was an early 16th-century urban wall at Dunbar, connecting the physical remains to the Act of 1503. There are definite traces only on the southern edge of the burgh - a substantial stone wall some $5.5 \mathrm{~m}$ high (Watson 1952) - with less clear evidence on the western side (Turner Simpson \& Stevenson 1981b, 17; Suddaby 2003). The original Scottish Burgh Survey saw the date and nature of any such town wall as a problem to be resolved, noting a 1548 x 1549 report of the lack of walls, the absence of any circuit on Blaeu's map of 1654 and observations of a decayed stone wall in 1706 and 1745 (Turner Simpson \& Stevenson 1981b, 16). At Dunbar, the three town ports may be earlier than any wall (Turner Simpson \& Stevenson 1981b, 5), but this is not certain.

Latest of all town walls would seem to be those of Haddington, scene of a long siege in 1548-49. Haddington's later walls, dating from 1597 onwards (Gourlay \& Turner 1978, 7), have more in common with the 'low stone dykes' shown by Slezer at the foot of Linlithgow's burgage plots (e.g. Dennison 2001, 126-27 and illus 125) than with the substantial, gunned defences of Edinburgh, Stirling, Dunbar, Peebles and Dundee.

W MacKay Mackenzie, in his Rhind lectures, noted several suggestive references to town walls at Glasgow from the early 14th century onwards (Mackenzie 1949, 42-43). This evidence is either minimised without investigation or simply not engaged with by later writers (e.g. Gibb 1983; Devine and Jackson 1995, $22 \&$ 108). The date of the defences of Kirkcudbright, which seem to have included a town wall, is not certain (Graham 1977, 176-77 \& fig 4). They were still extant at the time of the siege of 1547. The town wall of Lauder is similarly undated at present, being mentioned only as an existing feature in mid 16th-century and later sources (Turner Simpson and Stevenson 1980, 4 \& 15). The original Scottish Burgh Survey suggested that on Blaeu's map of East Lothian, published in 1654 but based on the later 16th-century survey work by Timothy Pont, walls are shown around North Berwick (Turner Simpson and Stevenson 1981c, 12). More recent writers are more sceptical of this evidence, capable of other explanations and not (yet) supported by remains on the ground (Hall and Bowler 1998, 667).

While for some years now suspicions have been expressed about the simple link between the construction of Edinburgh's Flodden Wall and the aftermath of the battle of Flodden (Section 4.2), or about the relationship between the Act of 1503 and actual burgh defences in Scotland, it is unfortunately not yet the case that better historical contexts have been provided for any of the 16th-century burgh defences listed above. As an example of what could be achieved, see Wolfe's analysis of 16th-century French walled towns (Wolfe 2000). In France, compelling circumstances for town defences only arose after the mid-14th century, when royal wishes coincided with local needs to allow the financing of such works. During the Wars of Religion, Wolfe argues that the earlier framework of municipal self-protection survived to allow the rapid repair and upgrade of urban defences.

It is not possible in this short review to make good the omissions and fully understand the Scottish mechanisms, but contemporary records claim the making of town walls as a response to particular times of crisis (Edinburgh, Stirling) while arranged over a period of a few years (Stirling, Peebles), show burgh councils delegating and contracting with named individuals for the work (Stirling, Peebles, Dundee) and reveal fortification by royal licence (Edinburgh, Dundee) or as a civic initiative (Peebles, Haddington).

Systematic investigations of the documentary evidence for Edinburgh's defences have tended to start from 1513 rather than any earlier date: in his account of Edinburgh's 16th-century defences Bryce reprints the post-Flodden proclamation, instructing the inhabitants to assemble in military array ' ... for the keiping and defens of the toun aganis thame that wald invaid the samyn ...' (Bryce 1909, 64; Scottish Burgh Records Society 1869, 143-44). In the accepted account, the key points are the resolution, as late as March 1514, that the sum of $£ 500$ Scots be 
raised to fortify the town and the provost's subsequent (May 1514) declaration that this extent [a land valuation for taxation purposes] be collected '. . for the strenthing of the saymn [i.e. the town], and furnesing of artailyerie for the resisting of the auld innemeis of Ingland. . . ' (Scottish Burgh Records Society 1869,146$)$. In the first item, '... the president baillies counsall and communitie hes grantit and consentit that ane extant be gatherit of the haill communitie extending to the sowme of 500 pounds, with the dettis awand to the toun for the furnesing and defens of the samyn, efter the forme and effect of our Souerane Lordis writings direct for that intent . . ' (Scottish Burgh Records Society 1869, 146). In the May declaration and others of October 1514, was mentioned the adaptation of existing boundaries (' . . . heidyaird dykes') to make a defensive line (Scottish Burgh Records Society 1869, $146,150 \& 151)$. There are further references to ' . . . the commoun walling of the toun ...' in the years up to 1518 (collected in Bryce 1909, 68) and works of repair and renewal (including the necessary taxation) were organised between 1557 and 1594 (Bryce 1909, 71-73).

Contemporary sources for the first building of the walls of Stirling (1547), Peebles (1570), Dundee (1591) and Haddington (1597) respectively state that:

money was to be raised over a three-year period '. . . to be expendit upone the strengthing and bigging of the wallis of the toun, at this present peralus tyme of neid, for resisting of oure auld innimeis of Ingland. . .' (Scottish Burgh Records Society 1887, 50);

'. . . the baillies counsale and communite of the burgh of Peblis, all in ane mynde and voce, is contentit that the toune and burgh of Peblis be wallit rownd about as thai think maist necessare, in maist sufficient place, as thai think maist expedient ... ' (Scottish Burgh Records Society 1872, 312);

'... the Council concludit that the town sall be fortified be ane wall, according to his Majesty's licence grantit to that effect ... the same sall be maist commodiously biggit, to the effect that the neighbours may bear burden therein according to their abilities ... ' (Dundee Burgh Register, February 1591, quoted in Maxwell 1884, 222),

while by the end of the century, worried by their undefended town's susceptibility to the theft of livestock and inability in time of plague to keep out 'suspect folk', the town council of Haddington '... haif concludit, all in ane voce, [that] ye toun salbe wallit \& stankeit about, with ane substantious wall ...' (Extracts from the Council Records of the Burgh of Haddington iii 1580-1599, 178 [November 1597]). The next month, one of their number was to purchase '. . . ane deid for walling of this toun ...', while the Parliament was in session (Extracts from the Council
Records of the Burgh of Haddington iii 1580-1599, 179 [December 1597]).

This report is no place for an extended discussion of the state of civic institutions in 16th-century Scotland, but it is worthwhile stepping back from the detail of particular 'projects' like the town walls to consider another aspect of their contexts. 'Mural ideology', as John Steane has dubbed it (Steane 2001, 194), is barely expressed in the Scottish burgh seals where towns like Edinburgh, Ayr, Dunbar, Kinghorn and Rothesay are instead symbolised as defended by castles (or ports/gates?). Aberdeen's seal shows walls and a gate, but probably only because it is depicting part of the legend of St Nicholas (Laing 1850, 208 \& pl. 29.1).

The organisation of the Medieval Scottish town allowed for the burgesses to establish trade; order was maintained and revenues collected by the burgh superior (the king or the bishop, abbot or baron) and his officers. The gradual emergence of selfgovernment in areas outside those of buying, selling and property rights can be seen in the relevant Edinburgh volume of the Scottish Burgh Records Society, where a 'maister of the werk' for the year was chosen in 1484 (Scottish Burgh Records Society $1869,50)$ and the baillies summarise a contract for the '... furnessing and completing of the towre of the Tolbuith ...' in 1500 (Scottish Burgh Records Society 1869, 89-90). We have already noticed royal commands to strengthen the burgh in 1450 and 1472 , rather than direct action being taken by the king. The published burgh accounts for the 16th century reveal that, though the provost, baillies and council were much concerned with levying taxes and raising money to further the interests of the trading community, major building projects do appear right at the start of the surviving town treasurers' accounts. For example, the New Well and a bulwark 'on the schoir of Leyth' in the time of Alexander Park, treasurer 1552-53 (Adam 1899, 77-101).

The difficulties of financing such an expensive project as the walling of Edinburgh are perhaps reflected in the extended date-range (1514-1518) noted above. This leads on to the idea that defence was not the most important motive for the provision of the town walls under discussion, or at least that vulnerabilities were dealt with by temporary measures while the grand circuit was slowly completed. Perhaps it seemed enough that the decision to fortify had been taken, as an expression both of civic self-confidence and mural ideology? The combined imperatives of defence and display, thought to be behind the monastic precinct fortifications mentioned earlier, are informative here and much useful recent work on town fortifications as artefacts of power is summarised by Steane (Steane 2001, 194-205).

The auxiliary idea of a town wall as an apparatus of control of any outsiders, cf. Haddington, rather than a seriously up-to-date defensive work, cf. the fortifications for the siege of Leith, links directly to an emerging difference of opinion in present-day 
urban studies. It is clear that not much work has been done on the distinction between the adaptation of existing burgage plot boundaries and buildings to make a defensive line ('strengthing', perhaps) and the creation of entirely new defensive works ('bigging', perhaps). The former, certainly the case in 15th-century Edinburgh, is often as much as those sceptical about the existence of burgh defences are prepared to concede in the majority of cases (e.g. Dennison 2001, 127 \& 130).

I argue that the sceptics have retreated too far, falling back beyond the military field to abandon consideration even of the visual image of the town wall as a symbol of power. After all, the 16th century was the time when the need was felt for such a landscape statement as an earthwork bank defining the border between Scotland and England in the western marches, inland from the Solway. Thus the Scots' Dike came into being in 1552 (Mackenzie 1951, 125; RCAHMS 1997, 47 \& fig 42). As we shift focus away from the accepted fact, repeated in all the books and papers on urban settlement history, that Scotland did not have many 14th/15th-century urban walls, towards the recognition that these things belonged instead to the 16th century, a suggestion can be made in order to provoke some new discussion. This is to take a view of the urban wall as another 16th-century symbol of power, the predecessor - in terms of civic building projects - to the later 16th and 17th-century provision of burgh Tolbooths or Town-houses (that were perhaps prompted by an act of the Scottish Parliament in 1597 requiring better jail provision: RCAHMS 1996, 2 ). At the very least, with the dates of the various Scottish town walls being widely spaced throughout the 16th century, the Act of 1503 may have played an important role in reinforcing the medieval, European suggestion that a high wall was appropriate to a town, quite as much as any particular Scottish set of political, religious or military events, or of contemporary outside influences. In time, if we can make use of the opportunities for archaeological research afforded to us by redevelopment schemes, the material remains of the relatively neglected subjects of urban symbolism, militarisation and demilitarisation in Scotland before the 17th century ought to receive more careful attention.

\subsection{Conclusions}

A town wall, generally lacking the sort of architectural detail that allows the chronology of buildings to be defined, will always pose problems of date when the documentary evidence is either unclear or uncollected. In the case of the Flodden Wall, the foundations for the original build were never exposed during the present excavations. The work showed that the foundations of the later rebuild were cut through man-made deposits (clay with rubble, and some bone and oyster shell: Section 3.1); the accumulation above both the foundation trench and these earlier deposits contained 18th-century material (Section 3.2).

Given the survival of the line of the Flodden Wall at the Dance Base site as an important property boundary to the present day, it may very well be that documentary research (on property deeds and on other material in the City Archives) can confirm or refute the suggestion made earlier (Section 4.2) that the prior existence of the West Port might be evidence for a pre-1514 date for the Flodden Wall along the north-western edge of the Grassmarket. Elsewhere, the original tower at the head of the Vennel is proposed on (unstated) architectural grounds to be no earlier than the second or third decades of the 16th century (RCAHMS 1951, lxiv) and the design of the Flodden Wall's gunloops have been compared to those of the Stirling Castle Forework of $1500 \times 1510$ (MacIvor 1981, 105). The circuit was extended in $1628 \times 1636$ (the Telfer Wall: Illus 1) and modifications to the Flodden Wall as a defensive structure are recorded up until 1715, before its gradual demise from the later 18th century onwards (RCAHMS 1951, lxvi). In that period the southern section of the Wall on the present site was largely rebuilt, when a complex of new buildings abutted the Wall's western (external) face (Section $3.2)$.

In an example of the management of change in a historic town, at the Scottish Dance Base an archaeological research opportunity - in a rescue context was successfully integrated into an urban redevelopment scheme. The building recording and archaeological watching brief met the conditions of the Scheduled Monument Consent. The work has allowed the original (Phase 1) Flodden Wall to be described and preserved; while no dating evidence was recovered, it became clear during the postexcavation work that the rebuilding of the southern section of the Wall in Phase 2 can be linked to the map evidence of third quarter 18th-century redevelopment in the Grassmarket area. In the intervening period, there was no evidence of activity from the excavated test pits. Large-scale landscaping on both sides of the rebuilt Wall in the mid-19th century (Phase 3) led to its truncation, while it continued to serve as a property boundary. 


\section{Acknowledgements}

David Henderson, formerly of CECAS, undertook much of the early fieldwork. We are grateful to Louise Baker and Jonathan Millar of Headland Archaeology Ltd for their help in completing the last phase of survey work. Jonathan Millar and Mike Middleton (Headland Archaeology Ltd) created illustrations $4,7 \& 10$ and prepared the final versions of all of them. All finds analysis was undertaken by John A Lawson (CECAS). We would also like to thank Malcolm Fraser, Helen Kelly, Callum Duncan and Clive Albert of Malcolm Fraser Architects for their help during the fieldwork and for the provision of additional information and the SAIR referee for their comments on the text. Colin Wallace is grateful to Veronica Wallace, of the Local History Centre, East Lothian Libraries for background assistance with his contribution, and to Raphael Isserlin for his comments. Last but not least, Olwyn Owen, Monument Inspector with Historic Scotland, monitored the Scheduled Monument Consent works and commented on the draft report. 


\section{References}

Adam, R (ed.) 1899 Edinburgh Records. The Burgh Accounts: Volume One I. - Baillies' Accounts, 1544-1566 II. - Town Treasurers' Accounts, 1552-1567. Edinburgh.

Adams, I H and Timperley, V 1988 Scottish Record Office Descriptive List of Plans Volume Four. Edinburgh.

Bowler, D Cox, A and Smith, C 1996 'Four excavations in Perth, 1979-84', Proc Soc Antiq Scot 125 (1995), 917-99.

Bryce, W Moir 1909 'The Flodden Wall of Edinburgh', Book of the Old Edinburgh Club 2 (1909), 61-79.

Caldwell, D H 1984 'A sixteenth-century group of gun towers in Scotland', Fort 12 (1984), 15-24

Coleman, R 1996 'Excavations at the Abbot's House, Maygate, Dunfermline', Tayside Fife Archaeol J 2 (1996), 70-112.

Cowan, W 1932 The Maps of Edinburgh 1544-1929 ( $2^{\text {nd }}$ edition). Edinburgh.

Curle, J 1935 'Melrose: The Precinct Wall of the Monastery and the Town', Hist Berwickshire Naturalists Club 29 (1935-37), 29-50.

Dennison, E P 2001 'Timothy Pont's Portrayal of Towns', in Cunningham, I C (ed.) The Nation Survey'd Essays on late sixteenth-century Scotland as depicted by Timothy Pont, 125-38. East Linton.

Dennison, E P and Coleman, R 1998 Historic Melrose the archaeological implications of development. Edinburgh.

Devine, T M and Jackson, G (eds.) 1995 Glasgow Volume I: Beginnings to 1830. Manchester.

Dixon, P J Mackenzie, J R Perry, D R and Sharman, P 2002 The origins of the settlements at Kelso and Peebles, Scottish Borders.

Edinburgh [ = Scottish Archaeological Internet Reports, 2: http://www.sair.org.uk (accessed 21.4.03)].

Edgar, W 1765 City and Castle of Edinburgh. Edinburgh

[http://www.nls.uk/digitallibrary/map/early (accessed 06.5.03)].

Ewart, G 1992 'Chambers Street. Multi-phase urban site', Discovery Excavation Scotland 1992, 50 .

Fraser, R Maxwell, R and Vaughan, J E 1994 'Excavation adjacent to Close Gate, Newcastle, 1988-89', Archaeol Aeliana 5th series 22 (1994), 85-151.

Geddy, J 1580 S. Andre sive Andreapolis Scotiae Universitas Metropolitana, National Library of Scotland MS 20996 [http://www.nls.uk/digitallibrary/map/early (accessed 01.11.03)].
Gibb, A 1983 Glasgow The Making of a City. Beckenham.

Gordon, J 1647 Edinodunensis Tabulam.

Amsterdam

[http://www.nls.uk/digitallibrary/map/early/ (accessed 06.5.03)].

Gourlay, R and Turner, A 1978 Historic Haddington the archaeological implications of development. Glasgow.

Graham, A 1977 'Kirkcudbright: Some Vanished Landmarks', Trans Dumfriesshire Galloway Nat Hist Antiq Soc 3ser 52 (1976-7), 173-77.

Hall, D and Bowler, D 1998 'North Berwick, East Lothian: its archaeology revisited', Proc Soc Antiq Scot 127 (1997), 659-75.

Harris, S 1996 The Place Names of Edinburgh Their Origins and History. Edinburgh.

Holinshed, R (ed.) 1577 The Chronicles of England, Scotlande, and Irelande. London

Holmes, N M McQ 1980 'Excavations at St Mary's Street, Edinburgh, 1974', Post-Medieval Archaeol 14 (1980), 157-84.

Kincaid, A 1784 A plan of the city and suburbs of Edinburgh. Edinburgh [http://www.nls.uk/digitallibrary/map/early (accessed 06.5.03)].

Kirkwood, R 1817 Plan of the City of Edinburgh and its Environs. Edinburgh [http://www.nls.uk/digitallibrary/map/early (accessed 30.10.03)].

Laing, H 1850 Descriptive Catalogue of Impressions from Ancient Scottish Seals, Royal, Baronial, Ecclesiastical, and Municipal. Edinburgh.

Lewis, J 1995 'Excavations at the former Lauder Technical College, Dunfermline', Proc Soc Antiq Scot 125 (1995), 1023-44.

MacIvor, I 1981 'Artillery and Major Places of Strength in the Lothians and the East Border, 1513-1542', in Caldwell, D H (ed.) Scottish Weapons and Fortifications 1100-1800, 94-152. Edinburgh.

MacIvor, I 1998 The Fortifications of Berwick-upon-Tweed. London.

MacKenzie, W M 1949 The Scottish Burghs. Edinburgh.

Mackenzie, W M 1951 'The Debateable Land', Scot Hist Rev 30 (1951), 109-25.

Maxwell, A 1884 The History of Old Dundee, narrated out of the Town Council Register, with additions from contemporary annals. Edinburgh.

Merriman, M 2000 The Rough Wooings Mary Queen of Scots, 1542-1551, East Linton.

NAS RHP4995 National Archives of Scotland, Stair Muniments. Plan of Mr Brown's property 
south side of Castle Hill, by James Campbell, Surveyor, Edinburgh [1810], reference RHP4995.

Nolan, J Fraser, R Harbottle, B and Burton, F C 1989 'The Medieval Town Defences of Newcastle upon Tyne: Excavation and Survey 1986-87', Archaeol Aeliana 5th series 17 (1989), $29-78$.

OS 1853 1st Edition Ordnance Survey. Edinburgh, Sheet 35 (1853), scale 6" to 1 mile. [http://www.nls.uk/digitallibrary/map/ townplans (accessed 21.8.03)].

OS 1877 2nd Edition Ordnance Survey. Edinburgh, Sheet 35 (1877), scale 6" to 1 mile. [http://www.nls.uk/digitallibrary/map/ townplans (accessed 21.8.03)].

RCAHMS 1933 Inventory of Ancient Monuments and Constructions in the Counties of Fife, Kinross and Clackmannan. Edinburgh.

RCAHMS 1951 An Inventory of the Ancient and Historical Monuments of the City of Edinburgh. Edinburgh.

RCAHMS 1956 An Inventory of the Ancient and Historical Monuments of Roxburghshire. Edinburgh.

RCAHMS 1963 Stirlingshire An Inventory of the Ancient Monuments. Edinburgh.

RCAHMS 1967 Peeblesshire An Inventory of the Ancient Monuments. Edinburgh.

RCAHMS 1996 Tolbooths and Town-houses Civic Architecture in Scotland to 1833. Edinburgh.

RCAHMS 1997 Eastern Dumfriesshire an archaeological landscape. Edinburgh.

Robertson, D Wood, M and Mears, F 1929 Edinburgh 1329-1929. Edinburgh.

Schofield, J 1978 'Excavations south of Edinburgh High Street, 1973-4', Proc Soc Antiq Scot 107 (1975-76), 155-241.

Scottish Burgh Records Society 1869 Extracts from the Records of the Burgh of Edinburgh, AD1403-1528. Edinburgh.

Scottish Burgh Records Society 1872 Charters and Documents of the Burgh of Peebles, with Extracts from the Records of the Burgh AD1165-1710. Edinburgh.

Scottish Burgh Records Society 1887 Extracts from the Records of the Royal Burgh of Stirling, AD1519-1666. Glasgow.

Simpson, A Turner and Stevenson, S 1980 Historic
Lauder the archaeological implications of development. Glasgow.

Simpson, A Turner and Stevenson, S 1981a Historic Inverkeithing the archaeological implications of development. Glasgow.

Simpson, A Turner and Stevenson, S 1981b Historic Dunbar the archaeological implications of development. Glasgow.

Simpson, A Turner and Stevenson, S 1981c Historic North Berwick the archaeological implications of development. Glasgow.

Simpson, A Turner, Stevenson, S and Holmes, N 1981 Historic Edinburgh, Canongate and Leith the archaeological implications of development. Glasgow.

Steane, J M 2001 The Archaeology of Power. Stroud.

Stell, G 1999 'Recording Scotland's urban buildings', in Dennison, P (ed.) Conservation and Change in Historic Towns Research Directions for the Future, York, 60-68 [ = Council for British Archaeology Research Report 122].

Stevenson, S and Torrie, E P D 1988 Historic Dundee the archaeological implications of development Part 2. Perth.

Suddaby, I 2003 'Lawson Place (138-140 High Street), Dunbar', Discovery Excavation Scotland new ser 2 (2002), 36.

Summerson, H 1993 Medieval Carlisle: The City and the Borders from the late Eleventh to the mid-Sixteenth Century. Kendal [ = Cumberland Westmorland Antiq Archaeol Soc Extra Series 25].

Tabraham, C 1973 'Edinburgh. Medieval Burgh', Discovery Excavation Scotland 1973, 64.

Thomson, T (ed.) 1814 The Acts of the Parliaments of Scotland Vol II AD MCCCCXXIV-AD $M D L X V I I$. Edinburgh.

Torrie, E P D 1990 Medieval Dundee A Town and its People. Dundee [ = Abertay Hist Soc Publ 30].

Watson, G P H 1952 “ 'Bamburgh's Castle' and Town Wall, Dunbar', Proc Soc Antiq Scot 84 (1949-50), 211-12.

Wolfe, M 2000 'Walled towns during the French wars of religion (1560-1630)', in Tracy, J D (ed.) City Walls The Urban Enceinte in Global Perspective, 317-48. Cambridge. 


\section{Index}

Act of the Parliament of Scotland, 1503 14-15

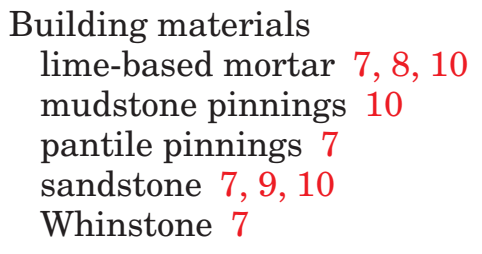

Clay pipe $8,9,10$

Edinburgh

Black Bull, well 9-10

Dance Base 3-4

Granny's Green 10, 13

Grassmarket 11, 13

Kings Wall 6, 14

West Port 11

\section{Flodden Wall}

Chambers Street 6

course of 11

Dance Base site 7

date $11-12,17$

depictions $11-12$

documentation 15-16

later history 17

as 18 th-century property boundary $7-9$

St Mary's Street 6

The Vennel 17

Map and plan evidence

Armstrong 177513

Edgar 176513

Gordon of Rothiemay 164712

Grassmarket 1810 (RHP4995) 10
Holinshed's Chronicles (Siege of Edinburgh Castle) 157311

Kincaid 1784 8, 12, 13

Kirkwood 181713

Ordnance Survey $1853 \& 187713$

Post Office Directory Plans 1807-1850 13

Pottery

18th/19th century earthenwares 8,10

Scottish post-medieval red ware (16th/17th centuries) 10

Scottish post-medieval reduced ware (16th/17th centuries) 10

Westerwald-type stoneware (16th/17th centuries) 9

Town walls

Berwick 14

Carlisle 14

Dunbar 15

Dundee 15, 16

Edinburgh (see Flodden Wall, Kings Wall)

France 15

Glasgow, possible 15

Haddington 15, 16

Inverkeithing, possible 15

Kircudbright, possible 15

Lauder, possible 15

Linlithgow 15

Mural ideology 16-17

Newcastle 14

North Berwick, improbable 15

Peebles 15, 16

Precinct walls (Dunfermline, Melrose, St Andrews) 14

Roxburgh 14

Stirling 15, 16 